Pacific Northwest

NATIONAL LABORATORY

\title{
Comparative Study of Barotrauma Risk during Fish Passage through Kaplan Turbines
}

\section{October 2015}

MC Richmond

P Romero-Gomez

JA Serkowski

CL Rakowski

M Graf 


\title{
DISCLAIMER
}

This report was prepared as an account of work sponsored by an agency of the United States Government. Neither the United States Government nor any agency thereof, nor Battelle Memorial Institute, nor any of their employees, makes any warranty, express or implied, or assumes any legal liability or responsibility for the accuracy, completeness, or usefulness of any information, apparatus, product, or process disclosed, or represents that its use would not infringe privately owned rights. Reference herein to any specific commercial product, process, or service by trade name, trademark, manufacturer, or otherwise does not necessarily constitute or imply its endorsement, recommendation, or favoring by the United States Government or any agency thereof, or Battelle Memorial Institute. The views and opinions of authors expressed herein do not necessarily state or reflect those of the United States Government or any agency thereof.

\author{
PACIFIC NORTHWEST NATIONAL LABORATORY \\ operated by \\ BATTELLE \\ for the \\ UNITED STATES DEPARTMENT OF ENERGY \\ under Contract DE-AC05-76RL01830 \\ Printed in the United States of America
Available to DOE and DOE contractors from the Office of Scientific and Technical Information, P.O. Box 62, Oak Ridge, TN 37831-0062;
ph: (865) 576-8401 fax: $(865) 576-5728$
email: reports@adonis.osti.gov
Available to the public from the National Technical Information Service
5301 Shawnee Rd., Alexandria, VA 22312 ph: (800) 553-NTIS (6847)
email: orders@ntis.gov <http://www.ntis.gov/about/form.aspx>
Online ordering: http://www.ntis.gov

This document was printed on recycled paper. 


\title{
Comparative Study of Barotrauma Risk during Fish Passage through Kaplan Turbines
}

\author{
MC Richmond ${ }^{1}$ \\ P Romero-Gomez ${ }^{1}$ \\ JA Serkowski ${ }^{1}$ \\ CL Rakowski ${ }^{1}$ \\ $\mathrm{M} \mathrm{Graf}^{2}$
}

October 2015

Prepared for

the U.S. Department of Energy

under Contract DE-AC05-76RL01830

Pacific Northwest National Laboratory

Richland, Washington 99352

\footnotetext{
${ }^{1}$ Hydrology Group, Pacific Northwest National Laboratory, Richland, Washington

${ }^{2}$ Voith Hydro, York, Pennsylvania
} 



\begin{abstract}
Rapid pressure changes in hydroelectric turbine flows can cause barotrauma that can be hazardous to the passage of fish, in particular migratory juvenile salmonids. Although numerous laboratory tests have evaluated the effect of rapid decompression in fish species of relevance, numerical modeling studies offer the advantage of predicting, for new turbine designs, the potential risks of mortality and injury from rapid pressure change during turbine passage. However, rapid pressure change is only one of several hydraulic risks encountered by fish during turbine passage in addition to blade strike, shear, and turbulence. To better understand the role of rapid pressure changes, the present work focuses on the application of a computational fluid dynamics based method for evaluating the risk of pressure-related mortality to fish passing through an early 1960s era original hydroelectric Kaplan turbine at Wanapum Dam (Columbia River, Washington), and a modern advanced Kaplan turbine installed in 2005. The results show that the modeling approach acceptably reproduced the nadir pressure distributions compared to field data previously collected at the site using an autonomous sensor. Our findings show that the new advanceddesign unit performs better, in terms of reduced barotrauma risk to fish from exposure to low pressures, than the original turbine unit. The outcomes allow for comparative analyses of turbine designs and operations prior to installation, an advantage that can potentially be integrated in the process of designing new turbine units to achieve superior environmental performance. Overall, the results show that modern turbine designs can achieve the multiple objectives of increasing power generation, lowering cavitation potential, and reducing barotrauma risks to passing fish.
\end{abstract}





\section{Acknowledgments}

This research was supported by the U.S. Department of Energy, Energy Efficiency and Renewable Energy, Wind and Water Power Program. Pacific Northwest National Laboratory (PNNL) is operated for the U.S. Department of Energy by Battelle under Contract No. DE-AC06-76RLO 1830.

We thank Brad Strickler and Curtis Dotson of Public Utility District No. 2 of Grant County, Ephrata, Washington for assisting with the project. We would also like to thank Susan Ennor of PNNL for editorial assistance.

We also thank Voith Hydro for access to the turbine geometries.

Computations described here were performed using the facilities of the PNNL institutional computing center (PIC). 



\section{Acronyms and Abbreviations}

$\begin{array}{ll}\text { AHT } & \text { Advanced Hydropower Turbine } \\ \text { BioPA } & \text { Biological performance assessment } \\ \text { CFD } & \text { computational fluid dynamics } \\ \text { GCPUD } & \text { Grant County Public Utility District } \\ \text { LRP } & \text { log of the pressure-change ratio } \\ \text { NMFS } & \text { National Marine Fisheries Service } \\ \text { ORG } & \text { Original } \\ \text { PNNL } & \text { Pacific Northwest National Laboratory } \\ \text { RANS } & \text { Reynolds-averaged Navier-Stokes } \\ \text { SF } & \text { sensor fish }\end{array}$





\section{Contents}

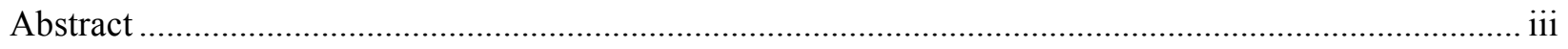

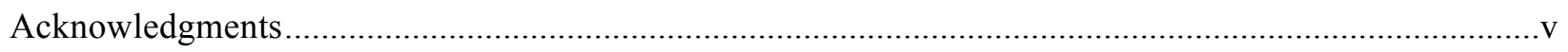

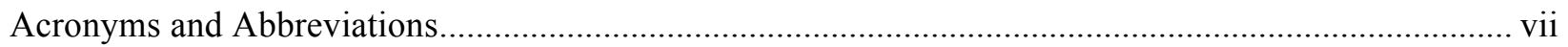

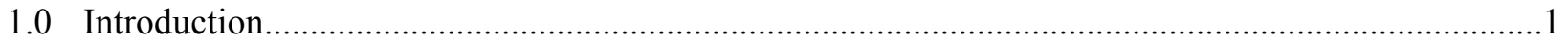

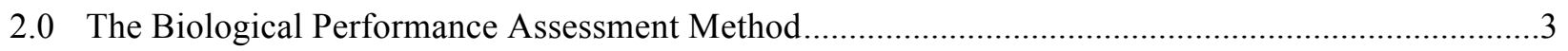

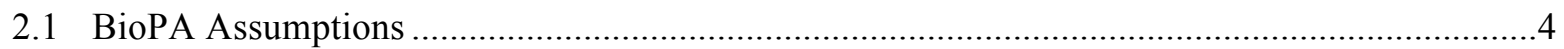

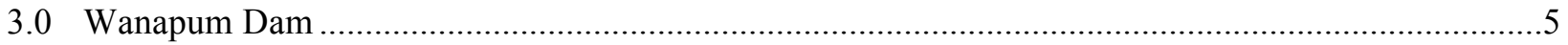

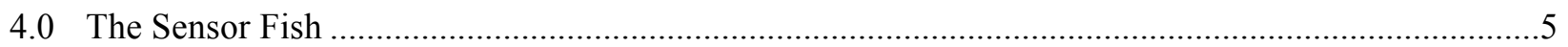

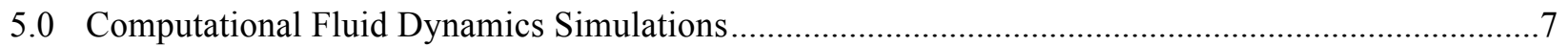

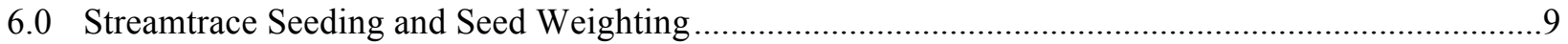

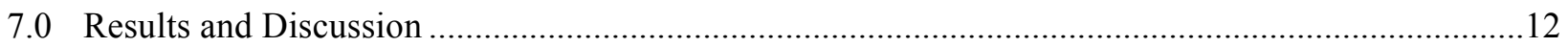

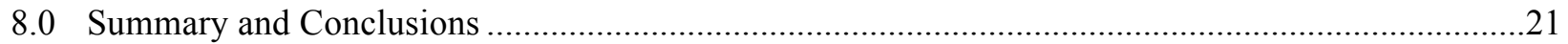

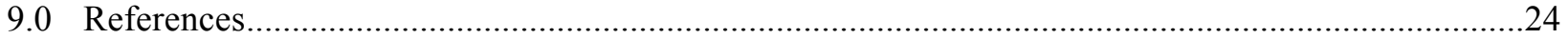




\section{Figures}

1 Probability of Mortal Injury for Juvenile Chinook Salmon at Various Acclimation Depths .....

2 The ORIG (left) and AHT (right) Units Showing the Stay Vanes, the Wicket Gates, the Blades and Hub

3 The CFD Model Included an Extended Intake, the Runner, the Draft Tube, and an Extended Outflow Region in Order to Improve Solution Convergence.............................................................

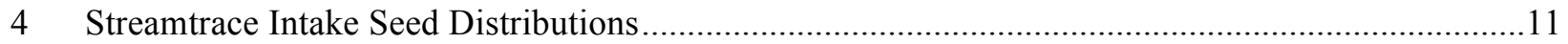

5 The Sensitivity of the BioPA Score to Fish Sample Entrainment was Conducted with a Uniform

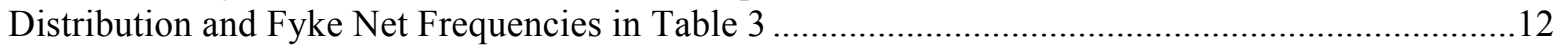

6 Example Trajectory of One Streamtrace from the 10-ft Release Pipe at the Center Bay...................15

7 Location of Nadir Pressures from all Streamtraces from the Uniform Turbine-intake Distribution,

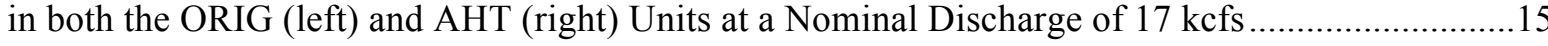

8 Nadir Pressure Frequency Distributions in the ORIG Turbine Design Cases are Computed from SF Data and the BioPA Calculations for Pipe Releases at $10 \mathrm{ft}$ (left) and $30 \mathrm{ft}$ (right) ...................16

9 Nadir Pressure Frequency Distributions in the AHT Turbine Design Cases are Computed from SF Data and the BioPA Calculations for Pipe Releases at $10 \mathrm{ft}$ (left) and $30 \mathrm{ft}$ (right)

10 Median and Range Values of Nadir Pressure for the ORIG (top figures) and AHT (bottom figures) Units from Pipe Releases at $10 \mathrm{ft}$ (left) and $30 \mathrm{ft}$ (right) in All Discharge Scenarios

11 An Example of the Quantitative Risk of Mortal Injury to the Fish Population in Treatment ORIG17, 10 ft-release Pipe.

12 BioPA- and SF-based Scores of Pressure Stressor from the $10 \mathrm{ft}$ (top) and $30 \mathrm{ft}$ (bottom) Release Pipes, for all Discharges

13 Median and Range Values of Nadir Pressure from the SF Data and Modeling Approach with Uniform and Fyke-net Seeding Schemes.

14 Pooled SF-based Scores and BioPA Scores from Fyke Net and Uniform Seed Distributions, for All Discharge Cases

15 Probability of Exposure and Mortal Injury (acclimation depth $5 \mathrm{~m}$ ) for ORIG17 Case 


\section{Tables}

1 Summary of Features of the ORIG and AHT Kaplan Turbines at Wanapum Dam ...........................6

2 Summary of the 2005 Biological Performance Field Test Cases that were Simulated and the Average Plant Estimated Discharge during the Tests...................................................................

3 Vertical Distribution of Fish Passage in the Wanapum Turbine Intake .............................................11

4 Summary of Computational Fluid Dynamics and Estimated Plant Average Values of

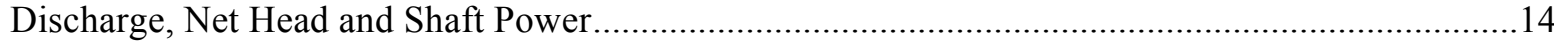





\subsection{Introduction}

The assessment of the environmental impacts of hydropower dams through- out the world has gained increased attention because dams affect the survival of anadromous fish species during their migration. In particular, the National Marine Fisheries Service (NMFS) lists, under the Endangered Species Act, a number of threatened and endangered species that include many salmonids of the U.S. Pacific Northwest, a region with abundant hydropower production. Historically, safe downstream fish passage was not a major factor in the original design and construction of many hydropower facilities. In the years following their construction, many Columbia River dams were retrofitted with fish-passage structures and/or their project operations were modified to meet requirements of the Federal Columbia River Power System Biological Opinion (NMFS 2008) or Federal Energy Regulatory Commission licensing requirements. The continuing need to improve protection of vulnerable species of fish has spurred research in the characterization of the flow environment of dam structures through which fish pass (Meselhe et al. 2000; Enders et al. 2003; Čada et al. 2006), the modification of project operations and structures (Coutant and Whitney 2000), and the measurement of fish response to hydraulic stressors (Neitzel et al. 2004; EPRI 2008; Brown et al. 2012b,c). Although many hydropower projects incorporate a number of routes for juvenile fish passage (e.g., spillways, bypass systems, transportation), some fish inevitably travel through the turbines, potentially encountering hazardous conditions (Cramer and Oligher 1964; Cada et al. 1997). Several laboratory, field, and numerical studies of fish passage through turbine flows have produced the basis for a framework of quantitative assessment of the biological performance of hydroelectric turbines (Normandeau Associates et al. 2005; Dauble et al. 2007; Richmond et al. 2014a). These integrative tools can be used for comparative studies of existing designs in the short term. Over the long term, turbine manufacturers can potentially include biological performance as an integral part of the design process for new projects or the rehabilitation of existing projects. This study presents a computational fluid dynamics (CFD)-based framework for quantifying the risks of mortal injury to fish populations from exposure to rapid pressure changes encountered during turbine passage. The simulation framework is applied to Wanapum Dam; first to compare the biological performance of a modern, fish-friendly advanced Kaplan turbine with the original turbine design, and then to compare results with field-measured pressure data reported by Dauble et al. (2007).

Over the course of the past three decades, various case studies and field tests have focused on identifying the factors responsible for mortality and injury to fish passing through hydroelectric turbines. A thorough review by (Coutant and Whitney 2000) described injury mechanisms associated with rapid decompression (barotrauma), mechanical strike, exposure to shear flows, and presence of cavitation. Not only could these stressors be present but also fish could be exposed to each of them during a single passage event, increasing the risk of mortal injury in comparison to the instance when a single stressor occurs (Richmond et al. 2014b,a). In view of the complexity associated with concurrent injury events, most studies have isolated each mechanism and evaluated its detrimental effects in passage survival.

The present study follows that approach, focusing on rapid decompression effects during fish passage through turbine flows.

The pressure environment within turbines is of long standing importance and has been characterized by reduced-scale physical models and numerical modeling because of its importance to hydraulic performance and cavitation (Nilsson and Davidson 2003; Liu et al. 2005). But rapid pressure changes in turbine flows are also relevant from an environmental standpoint because laboratory studies have shown them to potentially cause injury and mortality in juvenile salmonids (Brown et al. 2012b). CFD modeling (Keller et al. 2006) and field studies (Carlson et al. 2008) have shown that fish passing through turbines are subject to a mild compression at the turbine intake, followed by sudden decompression in the short period of travel from the stay vanes and wicket gates past the suction side of the runner blades. 
Laboratory experiments have enhanced our understanding of the effects of pressure changes on fish. Abernethy et al. (2001) and Abernethy et al. (2002) reproduced in the laboratory the rapid decompression typical of turbine passage to evaluate the response of rainbow trout (Oncorhynchus mykiss), Chinook salmon (O. tshawytscha), and bluegill sunfish (Lepomis macrochirus). They found the latter to be much more susceptible to swim bladder rupture than Chinook salmon, and no rupture to be present in rainbow trout. They also found the injury and mortality rates to be sensitive to the depth at which a fish attains neutral buoyancy described as its acclimation pressure. The dependence of these rates on acclimation pressure was further examined by Pflugrath et al. (2012) to determine the maximum median depth at which Chinook salmon can become neutrally buoyant $(6.7 \mathrm{~m})$.

Brown et al. (2012c) studied the mechanisms of barotrauma in fish and determined that injuries during decompression are caused by swim bladder expansion and rupture, or by gas bubble formation in blood (emboli). Other anadromous fish species such as the Pacific lamprey (Entosphenus tridentatus) lack a swim bladder, and therefore, were found to be nearly insensitive to the decompression occurring in operating turbine flows (Colotelo et al. 2012). Brown et al. (2012b) determined an empirical relationship between the mortal injury rate of juvenile Chinook salmon as a function of pressure change ratio (acclimation pressure/nadir pressure), a relationship used in this study.

In this work, we applied predictive numerical models for evaluating the risk of hazardous pressure changes on fish populations traveling through turbine flows using the biological performance assessment (BioPA) method by Richmond et al. (2014a). The method combines turbine flow characterization, sampling proportional to likely passage routes, and dose-response assessment to estimate risk. Herein we applied the BioPA method to original (1960s era) and modern Kaplan turbines at Wanapum Dam (located on the Columbia River in the U.S. Pacific Northwest) to compare the calculated biological performance, with respect to barotrauma, across turbine designs, discharges, and fish entrainment locations. This approach has a number of attractive features. First, the BioPA method uses turbine flow simulation techniques that are standard in the hydroelectric turbine industry (albeit typically at the physical model scale), thereby benefiting from, and expanding the use of, already existing modeling practices. Second, computer modeling can be a cost effective method compared to field studies that attempt to characterize the impact of turbine flow conditions on a sample of live fish or instrument packages. Third, the BioPA method provides quantitative risk evaluations a priori, as opposed to the field studies that are conducted a posteriori once the turbine is in place and fully operational. The BioPA predictive capability can also support experimental design of future field studies. The overall goal is to calculate biological performance metrics for turbines that can be easily included in the design workflow commonly used by turbine manufacturers.

The current version of the BioPA method does have limitations which include use of steady-state Reynolds-averaged Navier-Stokes (RANS) CFD modeling and streamtraces to estimate the hydraulic environment to which fish are exposed during passage. The method is also limited by the availability of dose- response data to relate exposure to mortality and injury for specific fish species and life stages. Further discussion of the assumptions of the method is presented in Richmond et al. (2014a).

This report is organized as follows: 1 ) the BioPA method is briefly explained (additional details can be found in Richmond et al. 2014a);2) the study site, the turbine designs, and the operating conditions are described; 3) the field studies used for comparison are detailed; 4) the CFD application is presented; and 5) streamtrace seeding and sensitivity are discussed. Results, discussion, and conclusions are provided at the end of the article. 


\subsection{The Biological Performance Assessment Method}

Previous computational studies of the risks of injury and mortality to fish passing through hydropower turbines have generally sought to identify potentially hazardous locations and the associated magnitude of hydraulic stressors (Ventikos et al. 1997; Garrison et al. 2002; Keller et al. 2006; Čada et al. 2006). In the BioPA method, we also seek to identify hazardous regions, but in addition, we estimate the probability that fish will travel through these hazardous regions. In this way hydraulic environments adverse to fish health are linked with the likelihood of exposure and ultimately a global probability of mortal injury to a fish population can be estimated for a particular turbine design and operating condition.

The BioPA is a software package developed at the Pacific Northwest National Laboratory (PNNL, Richland, Washington) as an effort to integrate and quantify the impact of multiple mechanisms of injury and mortality to fish passing turbines (Richmond et al. 2014a). The current full version of the BioPA code includes four hydraulic stressors: nadir pressure, maximum turbulent kinetic energy, maximum strain rate, and probability of blade-strike related mortality (Richmond et al. 2014b). In this study, we limit the scope of the analysis to only the effect of nadir pressure on fish.

Given a set turbine operation, a CFD simulation is used to determine the spatial distributions of velocity components, pressure, turbulent kinetic energy, and other derived quantities. Next, streamtraces are generated at prescribed seed (release) locations that are used to represent the potential fish trajectories through the turbine (further explained below in Section 6). Next, the absolute pressure is sampled along these trajectories. From all sampled pressure values nadir pressure (the lowest) is determined for each streamtrace. Last, we input the sampled nadir pressure $\left(P_{N}\right)$ exposure frequency together with a statistical dose-response model to estimate the potential biological risk to a fish population.

Laboratory barotrauma results for Chinook salmon were used by Brown et al. (2012b) to determine a relationship between mortal injury rate and the natural log of the pressure-change ratio (LRP):

$$
L R P=\ln \left(\frac{P_{A}}{P_{N}}\right)
$$

where $P_{A}$ is the acclimation pressure prior to passage and $P_{N}$ is lowest exposure pressure (sampled nadir pressure). LRP is the most influential variable in predicting injury.

An empirical formula for the probability of mortal injury is given by Brown et al. (2012a):

$$
P_{M O R T}\left(L R P \leq L R P_{i}\right)=\frac{e^{-5.56+3.85 x L R P_{i}}}{1+e^{-5.56+3.85 x L R P_{i}}}
$$

where the notation $P_{\text {mort }}\left(L R P \leq L R P_{i}\right)$ indicates the probability of mortal injury given that the LRP is less than or equal to a certain value of $L R P_{i}$. To illustrate how the dose-response model changes with different nadir and acclimation pressures, the relation (Eq. 2) is plotted in Figure 1 as a function of nadir pressure for three assumed values of acclimation pressure. In remainder of this study, we assumed that the acclimation pressure was equal to a water column of $5 \mathrm{~m}\left(P_{A}=150.3 \mathrm{kPa}\right)$, a depth that falls between the water surface and the maximum depth of neutral buoyancy for juvenile salmon as reported by Pflugrath et al. (2012) from laboratory observations. Note that currently there is no validated method to determine the state of acclimation for actively migrating fish in a river.

After the nadir pressures were determined for all streamtraces, the relative frequency distribution over a number (n) of nadir pressure bins were used to calculate the probability of exposure from the fish sample to a value of $P_{N}$, or $P\left(P_{N}\right)_{i}$. 


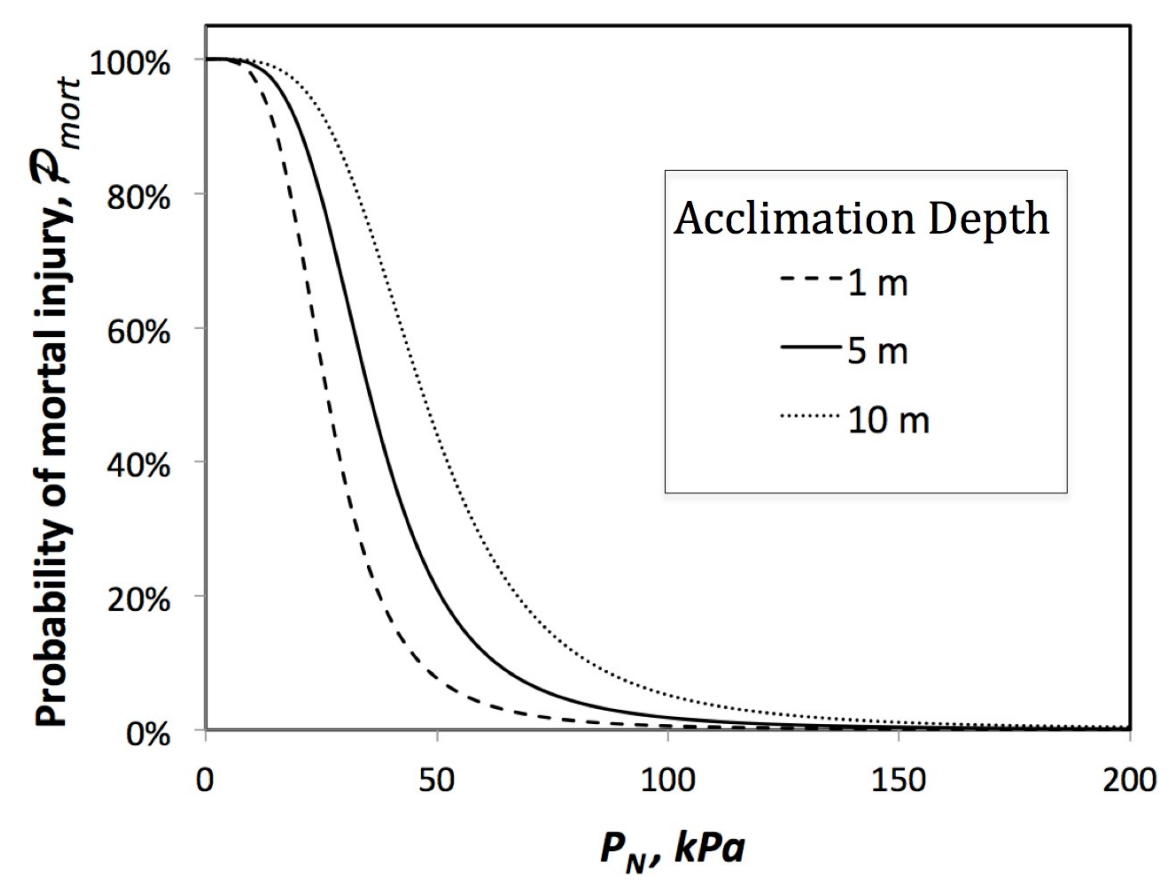

Figure 1. Probability of Mortal Injury (dose-response curves) for Juvenile Chinook Salmon at Various Acclimation Depths (Eq. 2). An acclimation depth of $5 \mathrm{~m}$ was used in all runs in this study.

The overall risk of mortal injury during passage was evaluated with the performance score, $\beta$, given by

$$
\beta=100 *\left(1-\sum_{i=1}^{n} P_{\text {mort }}\left(L R P \leq L R P_{i}\right) x P\left(P_{N}\right)_{i}\right)
$$

that accounts for the probability of exposure to the $i$-th bin, and its associated probability of mortal injury, $P_{\text {mort }}\left(L R P \leq L R P_{\mathrm{i}}\right)$. The score $(\beta)$ ranges from zero indicating that all sample fish experience mortal injury, to 100 indicating no mortal injury; thus, the higher the score is, the less risk of injury due to rapid pressure change during passage of fish through the turbine. This method was applied to compare scores across turbine types, operating conditions, and field sample release schemes. Note that the BioPA method and dose-response model (Eq. 2) do not currently include delayed mortality effects where fish may sustain a sub-lethal injury or become disoriented and then be susceptible to predation by birds or other fish downstream of the draft tube exit.

\subsection{BioPA Assumptions}

The underlying assumption of the current version of the BioPA method is that a large number of streamtraces will sample the potential pathways taken by fish through the turbine. A streamtrace is the path of a massless particle through a velocity field.

The CFD-simulated velocities are used to calculate the streamtraces. Each streamtrace samples the modeled hydraulic variables along its path through the turbine. 


\subsection{Wanapum Dam}

Grant County Public Utility District No. 2 (GCPUD) owns and operates Wanapum Dam, which is located in central Washington State on the Columbia River, $668 \mathrm{~km}$ upstream of the river mouth. The annual average discharge at Wanapum is $3398 \mathrm{~m}^{3} / \mathrm{s}\left(\sim 120,000 \mathrm{ft}^{3} / \mathrm{s}\right)$. The dam consists of a reinforced concrete powerhouse and spillway and a non-overflow earth fill section. Construction of the dam began in 1959 and power generation started in 1963. The 304.8-meter-long powerhouse contains 10 Kaplan turbine units. The 253-m long spillway has 12 Tainter-type radial gates.

A program to replace the original turbines with new units was initiated by GCPUD in the late 1990s with the objective of improving both hydraulic and environmental performance. The first replacement turbine was installed at the plant in 2005. The turbine units are referred to as the original (ORIG) and Advanced Hydropower Turbine (AHT) designs, respectively. Table 1 compares the characteristics of both turbine designs and Figure 2 shows the general features of each design. In the ORIG design, the wicket gates overhang the discharge ring, and the adjustments of blade angles create gaps at the hub and blade tips, a feature that potentially affects fish injury and mortality rates. In contrast, the Voith AHT design has a spherically-shaped hub and a discharge ring that minimize the gaps. The wicket gate overhang was eliminated in this design. In addition, the stay vanes were redesigned to enhance their alignment with the wicket gates and approach flow. These modifications were aimed at improving the flow environment for fish passage and hydraulic performance. The draft tube (not shown) was also redesigned to improve unit performance by reducing flow recirculation and turbulence. The AHT blade rotation axis elevation is approximately $1 \mathrm{~m}$ lower than the ORIG design; a feature that affects the resulting absolute pressure distribution in the runner region in addition to the blade shaping.

Table 2 shows the nominal plant operating conditions in 2005 during which Normandeau Associates et al. (2005) and Carlson et al. (2006) conducted field tests of passage conditions for live fish and sensor fish, respectively. Those same plant operating conditions were examined using the BioPA method.

\subsection{The Sensor Fish}

The BioPA results were compared to field measurements of nadir pressures recorded by an autonomous instrument package known as the sensor fish (SF). The SF is a device developed at PNNL (Carlson and Duncan 2003; Carlson et al. 2003, 2004; Deng et al. 2007) that records its response to the history of flow conditions experienced during passage through hydroelectric turbines and other hydraulic structures. The SF has been used in tests at turbines, spillways, and in laboratory-generated shear flows (Carlson et al. 2008; Richmond et al. 2007, 2009). Sensors contained inside the SF measure the three components of linear acceleration (up-down, forward-back, and side-to-side), three components of angular velocities (pitch, roll, and yaw), absolute pressure on its surface, and temperature. The sampling frequency is $2000 \mathrm{~Hz}$. The SF is nearly neutrally buoyant in freshwater and has a diameter of $24.5 \mathrm{~mm}$, length of $90 \mathrm{~mm}$, and weight of $42 \mathrm{~g}$. A piezoresistive silicon sensor measures pressure on the surface of the SF over a range of 0 to $689 \mathrm{kPa}(0-100 \mathrm{psi})$ with a resolution of $0.689 \mathrm{kPa}(0.1 \mathrm{psi})$. Laboratory tests in a hyperbaric chamber showed a pressure sensor accuracy of $\pm 1.378 \mathrm{kPa}( \pm 0.2 \mathrm{psi})$. More details about ranges and sensitivities of the measurements, bench-top performance testing, and other features of the device are described by Deng et al. (2007). 
Table 1. Summary of Features of the ORIG and AHT Kaplan Turbines at Wanapum Dam

\begin{tabular}{lcc}
\hline & ORIG & AHT \\
\cline { 2 - 3 } Manufacturer & Dominion Engineering & Voith Siemens Hydropower \\
\hline Hydraulic capacity $\left(\mathrm{m}^{3} / \mathrm{s}\right)$ & 402 & 504 \\
Rated power output $(\mathrm{MW})$ at & 89.48 & 111.85 \\
24.4 m-net head & 5 & 6 \\
Number of blades & 7.24 & 7.75 \\
Runner diameter $(\mathrm{m})$ & 16 & 16 \\
Number of stay vanes & 20 & 32 \\
Number of wicket gates & 0.851 & 0.546 \\
Wicket gate spacing $(\mathrm{m})$ & 85.7 & 85.7 \\
Runner rotation $(\mathrm{RPM})$ & & 0.254 \\
\hline Hub gaps $(\mathrm{cm})$ & $0.305-12.421$ & 0.254 \\
\hline Leading edge & 0.305 & 0.787 \\
Trailing edge & & 0.787 \\
\hline Blade tip gaps $(\mathrm{cm})$ & $1.930-9.703$ & \\
\hline Leading edge & $1.930-30.963$ & \\
Trailing edge & & \\
\hline
\end{tabular}

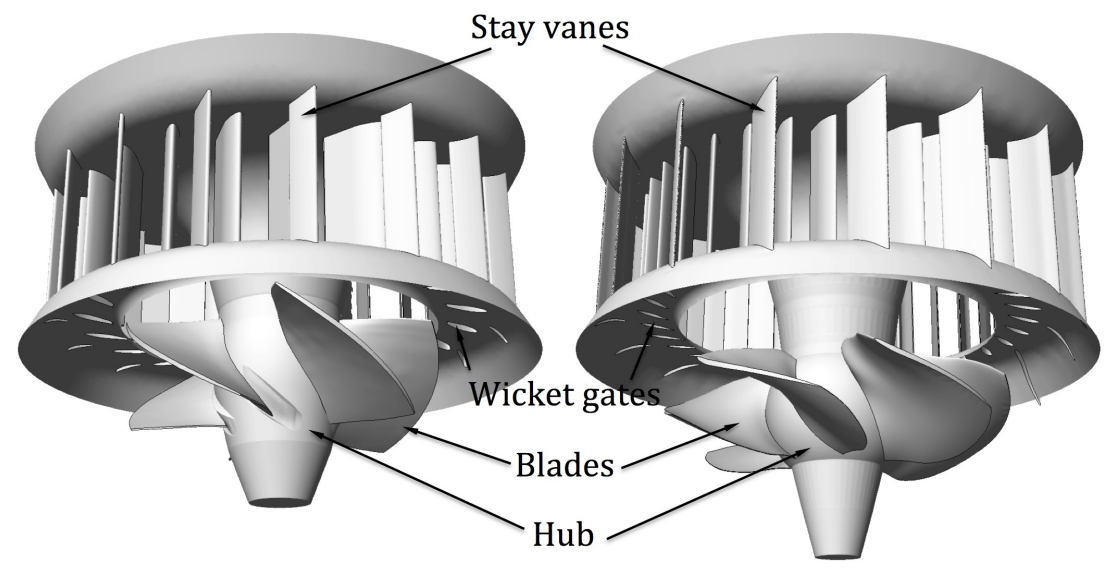

Figure 2. The ORIG (left) and AHT (right) Units Showing the Stay Vanes, the Wicket Gates, the Blades and $\mathrm{Hub}$ 
Table 2. Summary of the 2005 Biological Performance Field Test Cases that were Simulated and the Average Plant Estimated Discharge during the Tests

\begin{tabular}{cccc}
\hline \multirow{2}{*}{ Design } & $\begin{array}{c}\text { Nominal Discharge Case, } \\
\text { kcfs }\end{array}$ & Case Name & Estimated Discharge, $\mathrm{m}^{3} / \mathrm{s}$ \\
\hline \multirow{3}{*}{ ORIG } & 9 & ORIG09 & 253.32 \\
& 11 & ORIG11 & 308.40 \\
& 15 & ORIG15 & 421.67 \\
& 17 & ORIG17 & 472.89 \\
AHT & 9 & AHT09 & 250.77 \\
& 11 & AHT11 & 306.87 \\
& 15 & AHT15 & 415.97 \\
\hline
\end{tabular}

Ideally, comparisons of hydraulic data from CFD or laboratory models to SF data should occur at identical spatial locations. Because the SF does not record its exact location during turbine transit, the SF location has to be assigned to general zones within the turbine. For example, the general location could be the runner zone downstream of the wicket gates and upstream of the draft tube (e.g., Dauble et al. 2007). In addition, the SF records the pressure on the surface of the instrument housing which will not necessarily correspond to the local static pressure simulated by the CFD model if the SF is in relative motion to the fluid or collides with a solid surface. Depending on the magnitude of relative motion (slip velocity), which is not known, the SF will experience a non-uniform pressure distribution on its surface akin to that occurring on an airfoil. Therefore, for this analysis, we assumed a negligible slip velocity and performed statistical comparisons of the pressure distributions recorded by the SF and those simulated by CFD as sampled by streamtraces. In the future it may be possible to improve the SF and associated data processing to reduce these uncertainties.

\subsection{Computational Fluid Dynamics Simulations}

CFD simulations were conducted to model the flow conditions in the two hydropower turbines and their associated structures (e.g., intake, distributor, wicket gates, and draft tube) in the computational domain is shown in Figure 3. CFD models have been extensively used to simulate turbine flow conditions and numerous studies have documented the flow conditions for different turbine designs (Nilsson and Davidson 2003; Roh et al. 2010), and for supporting structures such as the turbine intake (Khan et al. 2004) and the draft tube (Paik et al. 2005; Hellstrom et al. 2007; Galvan et al. 2011).

Turbine geometries were provided by Voith Hydro for each design with wicket gate angles and blade tilt settings appropriate for each discharge ( 2 designs $\times 4$ discharges $=8$ geometries). Extensive tests of computational mesh and simulation parameters were performed. Tests included the sensitivity to mesh density, cell allocation per region (intake, runner, draft tube), cell type (hexahedral or polyhedral), runner rotational angle position, wall layer resolution, and number of iterations to achieve convergence. 
The commercial code STAR-CCM+v8 (CD-adapco 2013) was used to generate polyhedral meshes with $20.8 \mathrm{M}-22.6 \mathrm{M}$ cells for the ORIG design and 24.5 M - 26.0 M cells for the AHT unit. The difference in mesh size between the two designs was driven by the number of blades ( 5 for the ORIG and 6 for the AHT). The mesh was considerably refined near the blades to better capture the expected large flow gradients. The polyhedral meshing tool created cells with an average of 14 faces, which allowed for less stretching of the cell, and consequently, for aspect ratios near to one in the core mesh. The partition of cells in the regions of the domain was about $30 \%$ in the intake, $45 \%$ in the runner (blades region), $20 \%$ in the draft tube, and 5\% in an outflow region that extended past the draft tube exit. The latter downstream extension region minimized flow recirculation at the outlet and improved convergence (Figure 3 ).

A mesh dependency test of the model was conducted in both models at nominal discharge of $17 \mathrm{kcfs}$. Mesh sizes in the ORIG model were $1.1 \mathrm{M}, 2.2 \mathrm{M}, 6.5 \mathrm{M}$, and $20.8 \mathrm{M}$; in the AHT model they were 1.3 M, 2.5 M, 6.9 M, 25.9 M, and 48.8 M. Because no significant difference in computed power (less than $0.2 \%$ ) was observed between the latter two mesh densities for each design, we used the $20.8 \mathrm{M}$ and 25.9 $\mathrm{M}$ sizes as reference mesh densities for discretizing the other discharge scenarios in the ORIG and AHT models, respectively.

The simulations were run on a mid-scale parallel computing cluster using between 48 and 96 processors. Simulations were run in steady-state mode, using 2nd order solution methods, with the rotating region treated using a multiple reference frame procedure, and a segregated flow solver. Turbulence was modeled with the RANS version of the $\kappa-\omega$-SST turbulence model with a wall function that imposed either a low-y ${ }^{+}$or high-y ${ }^{+}$treatment according to the localized conditions ("All $\mathrm{y}^{+}$wall treatment," in CDadapco 2013). This wall function is also applicable for mesh $\mathrm{y}^{+}$values that fall in the buffer zone. The average $\mathrm{y}+$ of the wall cells was approximately 20 at the stay vanes, wicket gates, blade surfaces, and draft tube walls, i.e., at boundaries were large velocity gradients are expected. The upstream boundary condition was a uniform inflow velocity calculated from the prescribed discharge (Table 2). Both the upstream and downstream water surfaces were modeled as symmetry planes, and the outlet was set to a constant working pressure of zero. This outlet pressure was later used in post-processing to compute the absolute fluid pressure by accounting for the hydrostatic pressure component. The runner section was modeled using a rotating reference frame with interfaces to the upstream and downstream stationary regions. Between the intake and runner section, a direct interface was used to indicate no physical separation between the two regions. Between the runner and the draft tube, a circumferentially-averaged interface of the "mixing-plane" type was set up as recommended for turbo-machinery flows (CD-adapco 2013).

Each model was run until the conservation equation residuals were reduced by at least three orders of magnitude. Then, the simulation was continued until the values of power, net head, and draft tube outflows also reached convergence. Typically, about 10,000 total iterations were required for most simulations. 


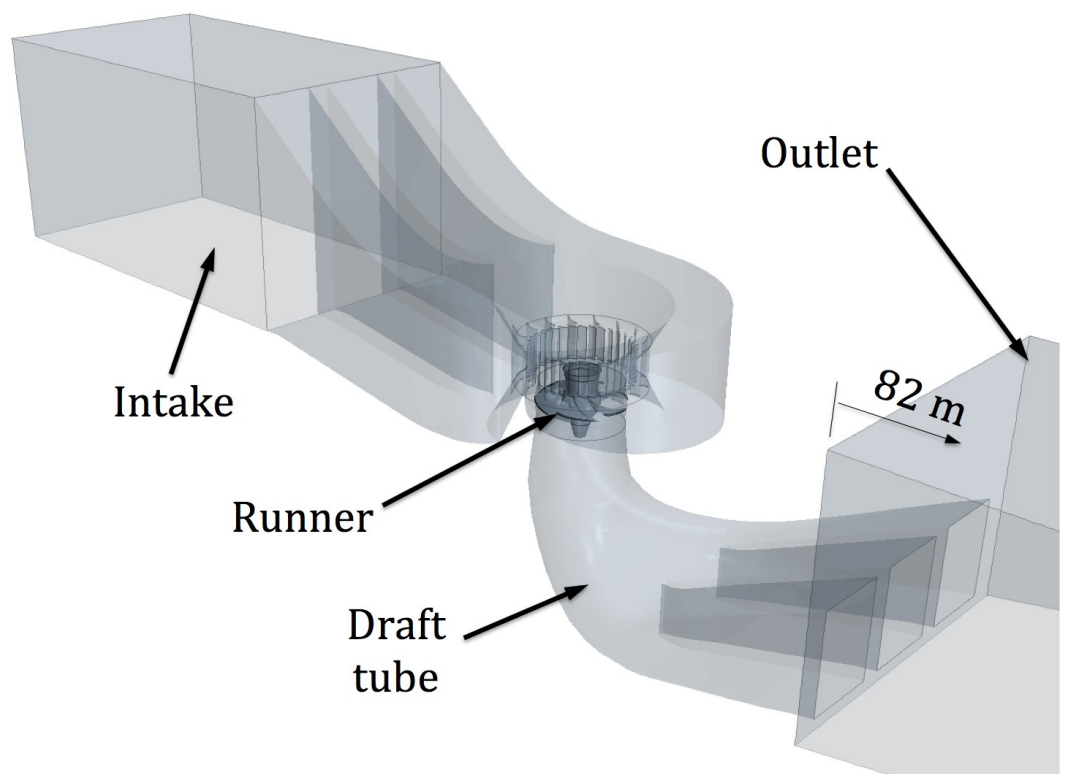

Figure 3. The CFD Model Included an Extended Intake, the Runner, the Draft Tube, and an Extended Outflow Region in Order to Improve Solution Convergence

The CFD results were compared with plant operations data provided by GCPUD for the time periods corresponding to the 2005 field tests. Each modeled scenario in Table 2 was compared to estimates of the averages of unit discharge, net head, and turbine output power. At the plant, the unit discharge was estimated with the Winter-Kennedy method, the net head was defined as the gross head minus a head loss calculated with an empirical equation, and the output power was calculated from the measured generator power divided by its estimated efficiency.

The CFD flow solution was exported into a Tecplot $360^{\mathrm{TM}}$ file for use with the BioPA software. The BioPA software was run on a Dell Precision T7500 computer with 12 processors and 96 GB RAM running the Microsoft Windows 7 operating system.

\subsection{Streamtrace Seeding and Seed Weighting}

To estimate risk to a downstream migrating fish population, the origin (or seed) of the streamtraces should be representative of observed fish distributions entering the turbine intake. In most applications, a generic uniform distribution is assumed, unless site- and species-specific fish distribution data are available. Actual fish distributions in turbine intakes can be observed in the field using different approaches, e.g., fyke nets, video imaging, and hydro-acoustic methods (Coutant and Whitney 2000). When field tests using point releases of live fish or SF are to be replicated, streamtrace seeds should be placed at the release pipe exit location within the turbine intake. In this study, three fish distributions were represented with three streamtrace seed schemes: the pipe-release locations from the live fish and SF studies conducted in 2005, a uniform turbine-intake population distribution, and a population distribution based on field-measured fyke-net data. The first distribution was used to compare the BioPA calculated nadir pressure distributions with SF-measured distributions from the field tests. The two population distributions were used to test the sensitivity of nadir pres- sure distribution and consequent mortal injury estimates to the seeding location (Figures 4 and 5) and to compare the biological performance of the two turbines. 
Pipe-release distribution - The pipe-release distribution represented the location of the release tube exits for live and SF samples in the Wanapum Dam field tests (Dauble et al. 2007; Deng et al. 2010). The release pipe exits at the head gate slot were positioned $3.05 \mathrm{~m}$ and $9.14 \mathrm{~m}(10 \mathrm{ft}$ and $30 \mathrm{ft})$ below the intake ceiling in all three intake bays. Because the CFD models were steady- state and the streamtraces do not account for turbulent dispersion, a release corresponding to the pipe exit will result in a single nadir pressure value. This would not allow for a statistical evaluation of the passage conditions. For that reason, streamtraces were instead seeded in a uniform rectangular array of $1.22 \mathrm{~m} \times 1.22 \mathrm{~m}$, centered at the release-pipe locations (Figure 4) to efficiently mimic, within the limitations of a steady state model, the spreading caused by turbulent dispersion. The total number of seeds for the six pipes $(2$ pipes per intake bay and 3 intake bays) was 4332. The streamtraces sampled a limited region over the passage plane above the blades. To account for the turbine rotation, which leads to stream traces entering the runner zone in variable locations relative to the moving blades, these sampled regions were circumferentially spread with a seed-weighting strategy (described at the end of this section) to be more representative of the distribution relative to the runner blades.

Uniform distribution - The reasons to test a uniform turbine-intake distribution were twofold. First, a uniform distribution of seeds implied that a fish had an equal probability of entering the turbine at any location on the seeding plane (Figure 5, left side). This maximized the extent to which the entire flow environment was sampled, because all possible ingress locations were accounted for. Furthermore, it provided a means to cross compare turbines and operating conditions in situations where field observations of fish distributions were not available. Second, the uniform distribution was used as the starting point to calculate seed weights to represent other realistic, non-uniform fish distributions by means of seed weighting (see explanation below). The total number of seeds for this distribution was 7560 .

Fyke-net distribution - Previous studies of fish distributions in turbine intakes have reported nonuniform distributions (Coutant and Whitney 2000). Olson (1984) evaluated the vertical passage distribution of yearling Chinook salmon entering a turbine at Wanapum Dam. The fyke-net data were summarized as a fish distribution at depth intervals below the turbine intake ceiling (Table 3 ). Here, the fyke-net distribution was represented by weighting the results from the uniform distribution (Figure 5, right side).

Seed weighting enables computing the streamtraces once from a uniform distribution (Figure 5, left side) and then post-processing those results into any target non-uniform seed distribution (provided it covers the entire intake cross section). In addition, seed weighting helps to minimize potential sampling bias due to the use of a steady-state model with a fixed set of turbine runner blade locations relative to the stay vanes and wicket gates. For example, the pipe-release seeds in Figure 4 tended to form three clusters near the hub as they arrived at a crossing plane above the blades. To correct for this clustering effect, a spreadsheet application was used to calculate the radial distribution of passage locations. This distribution was applied on the crossings arising from a uniform seed distribution (Figure 5, left side), thereby capturing the circumferential variability relative to the actual moving blades by using a ring of weighted seeds (Figure 4, bottom frames). 


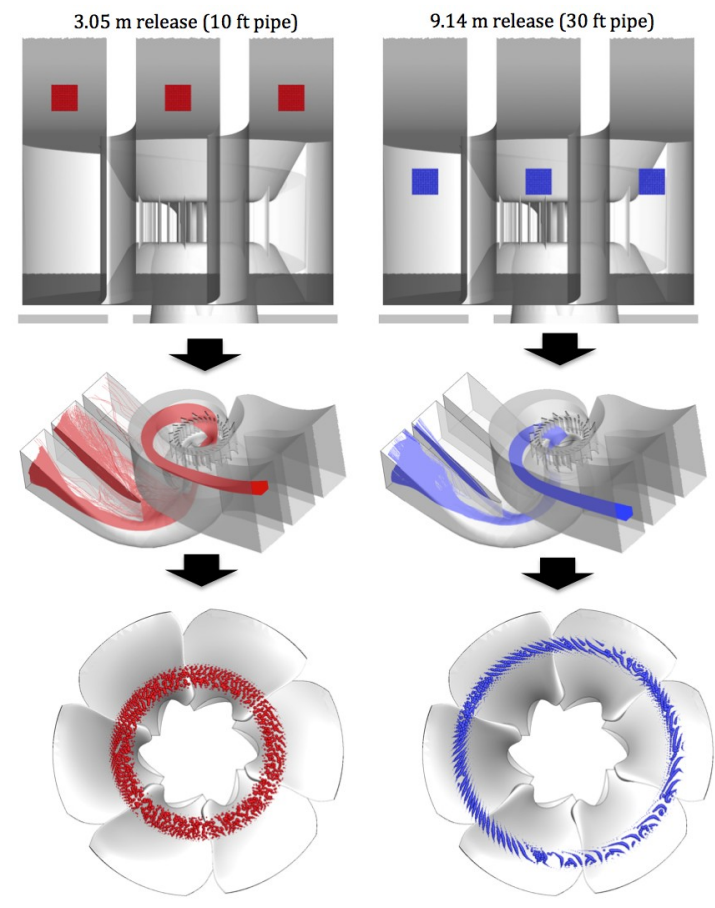

Figure 4. Streamtrace Intake Seed Distributions (top), Trajectories through the Model (middle), and the Corresponding Runner Plane Crossing Locations (bottom) for Example Case AHT17, from both Release Pipes (indicated with red [3.05 m] and blue [9.14 m] markers)

Table 3. Vertical Distribution of Fish Passage in the Wanapum Turbine Intake (Olson 1984)

\begin{tabular}{cc}
\hline Depth interval below turbine intake ceiling, $\mathrm{m}$ & Frequency, $\%$ \\
\hline $0.00-1.83$ & 27.67 \\
$1.83-366$ & 30.58 \\
$3.66-5.49$ & 20.12 \\
$5.49-7.32$ & 8.55 \\
$7.32-9.14$ & 4.72 \\
$9.14-10.97$ & 4.43 \\
$10.97-12.80$ & 2.62 \\
$12.80-14.64$ & 1.31 \\
14.63 to intake floor & 0.00 \\
\hline
\end{tabular}




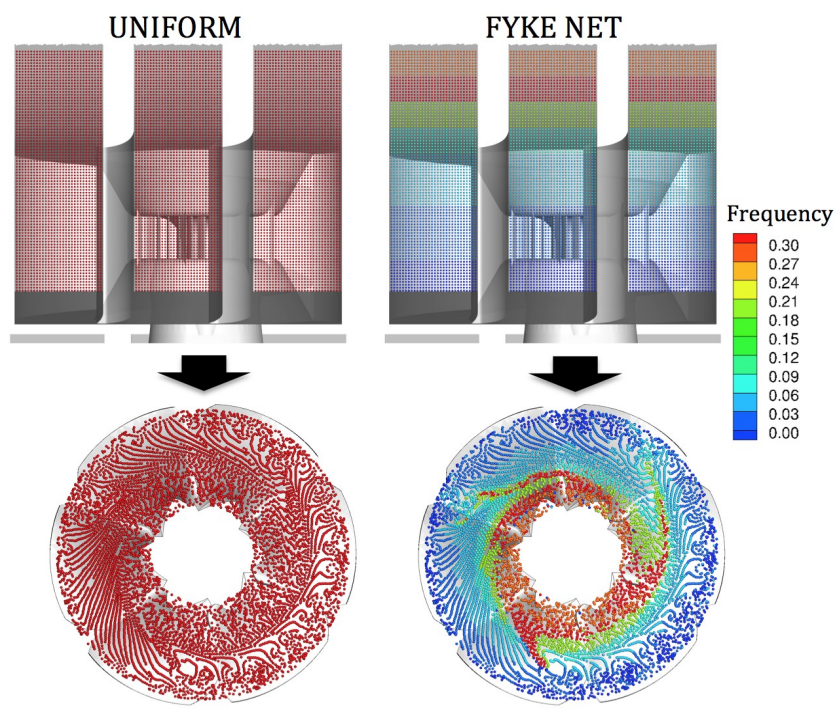

Figure 5. The Sensitivity of the BioPA Score to Fish Sample Entrainment was Conducted with a Uniform Distribution and Fyke Net Frequencies in Table 3 (Olson 1984)

\subsection{Results and Discussion}

Power values calculated from preliminary CFD simulations differed from those estimated at Wanapum Dam (Table 4, left column). GCPUD (personal communication) suggested that the mismatch was partly explained by the need for recalibrating the discharge estimate equipment at the dam (Winter-Kennedy method) for the old unit and by possibly by intake headloss from features not included in the CFD model such as trash racks and gate slots. Because generator power measurements were considered to be more reliable than the discharge estimates for short converging intakes, we iteratively adjusted the inflow discharge until the simulated shaft power values closely agreed with field estimates based on measurements of generator power (assuming a 2\% loss). The updated models produced discharges approximately $5 \%$ greater for the ORIG unit and within $\pm 2 \%$ of the discharge estimates for the AHT (Table 4). This approach was taken to have simulations that would better represent pressure conditions within the runner blade region of the turbine that were present during the field tests.

As a consequence of the discharge adjustment, the simulated net head deviated from the field estimates within a range from $-0.96 \mathrm{~m}$ (ORIG09) to $1.45 \mathrm{~m}$ (AHT15). The discrepancy in net head had two main sources. First, as expected from turbine performance curves, the results are sensitive to the combination of net head, flow rate, and power output. In this instance, the adjusted dis- charges had a direct effect on the net head deviations. Second, the method by which the net heads were calculated were essentially different between the dam and the model. In the field estimates, a head loss is estimated by an empirical relationship based on discharge, and subtracted from the difference in forebay and tailrace water surface elevations (gross head). In the CFD models, net head was computed from the simulated pressure and velocity results at two stations (planes) in the intake and draft tube.

To estimate the risk of barotrauma in fish due to the lowest exposure pressure, the first step in the process consisted of comparing the distributions of nadir pressures from the BioPA calculations with available nadir pressures from the SF field data. Figure 6 shows an example pathway of one streamtrace released from a 10-ft elevation pipe in the center bay; the pathway is colored by modeled absolute pressure.

Richmond et al. (2014a) illustrated that nadir pressures are, as expected, heterogeneous with locations that typically lie under the suction side of the turbine blades. Figure 7 shows that nadir pressure values were 
lower in the ORIG17 than in the AHT17 case. This trend was replicated in the other discharges. The majority of nadir pressure locations were spread under the blades because the uniform seed distribution tended to maximize the sampling area. Pipe-release seed distributions, on the other hand, gave rise to clusters of nadir pressure locations within confined regions under the blades (not shown), which illustrate that single-point pipe-releases - in both field tests and laboratory models - sample limited regions of turbine flows. 
Table 4. Summary of Computational Fluid Dynamics and Estimated Plant Average Values of Discharge, Net Head and Shaft Power

\begin{tabular}{|c|c|c|c|c|c|c|c|c|c|}
\hline \multirow[b]{2}{*}{ Case Name } & \multirow[b]{2}{*}{$\mathrm{Q}, \mathrm{m}^{3} / \mathrm{s}$} & \multicolumn{2}{|l|}{ CFD } & \multicolumn{3}{|c|}{ Wanapum Plant } & \multicolumn{3}{|c|}{ Error Relative to Plant Estimate } \\
\hline & & $\begin{array}{l}\text { Net Head, } \\
\text { m }\end{array}$ & Power, MW & $\mathrm{Q} \mathrm{m}^{3} / \mathrm{s}$ & $\begin{array}{l}\text { Net Head, } \\
\text { m }\end{array}$ & Power, MW & $\mathrm{Q}, \%$ & $\begin{array}{l}\text { Head, } \\
\%\end{array}$ & Power, \% \\
\hline ORIG09 & 265.22 & 22.41 & 51.38 & 253.32 & 23.37 & 51.45 & 4.7 & -4.1 & -0.1 \\
\hline ORIG11 & 324.28 & 23.18 & 62.79 & 308.40 & 23.30 & 62.86 & 5.2 & -0.5 & -0.1 \\
\hline ORIG15 & 443.64 & 22.91 & 85.38 & 421.67 & 23.09 & 85.38 & 5.2 & -0.8 & 0.0 \\
\hline ORIG17 & 498.40 & 22.88 & 94.70 & 472.89 & 22.96 & 94.78 & 5.4 & -0.3 & -0.1 \\
\hline АНT09 & 246.27 & 23.61 & 52.50 & 250.77 & 23.36 & 52.50 & -1.8 & 1.1 & 0.0 \\
\hline AHT11 & 300.44 & 24.19 & 65.17 & 306.87 & 23.29 & 65.25 & -2.1 & 3.8 & -0.1 \\
\hline AHT15 & 419.46 & 24.56 & 88.51 & 415.97 & 23.11 & 88.44 & 0.8 & 6.3 & 0.1 \\
\hline AHT17 & 478.10 & 23.85 & 99.18 & 472.13 & 22.95 & 99.10 & 1.3 & 3.9 & 0.1 \\
\hline
\end{tabular}


Figures 8 and 9 show the nadir pressure distributions from both SF data and BioPA results. The plots are presented for both the ORIG (Figure 8) and AHT (Figure 9) designs, from the 10-ft and 30-ft elevations (left and right plots, respectively) for the four discharge cases. The frequency distributions of nadir pressures from SF consisted of limited sample sizes ranging from 40 to 50 for each field test treatment. The BioPA distributions were obtained from 4332 weighted-value nadir pressures. As previously explained, the weights represented a correction factor for the discrete sampled nadir pressures from the uniform distribution to simulate pipe-releases. This correction scheme precluded the presence of an absolute maximum and minimum in the weighted sample. Therefore, the statistical measures were different in each data source. We com- pared the minimum, median, and maximum values from SF data to the 1-, 50-, and 99-percentiles from BioPA frequency distributions, respectively.

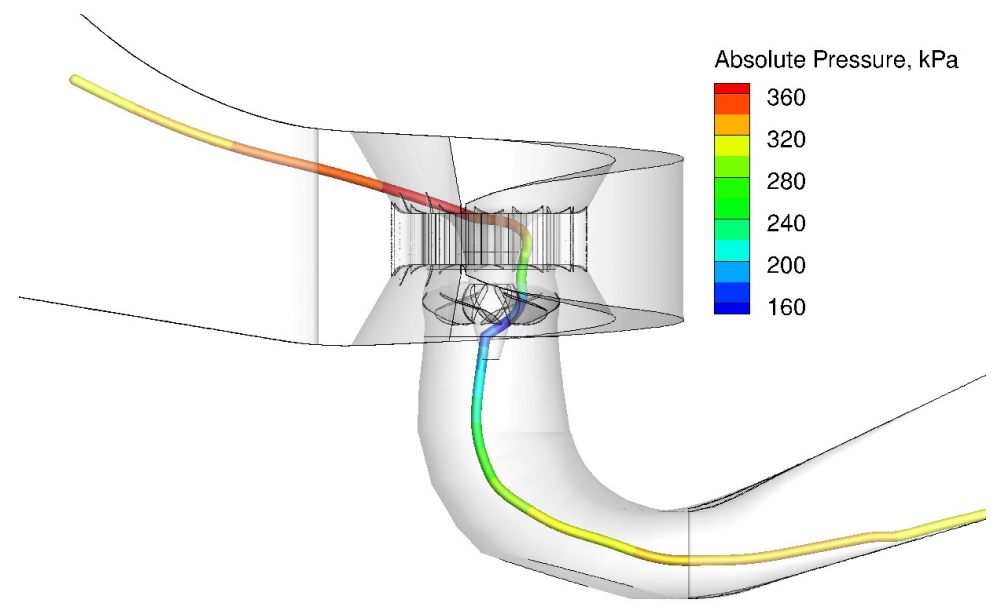

Figure 6. Example Trajectory of One Streamtrace from the 10-ft Release Pipe at the Center Bay. Pathway is colored by absolute pressure $(\mathrm{kPa})$

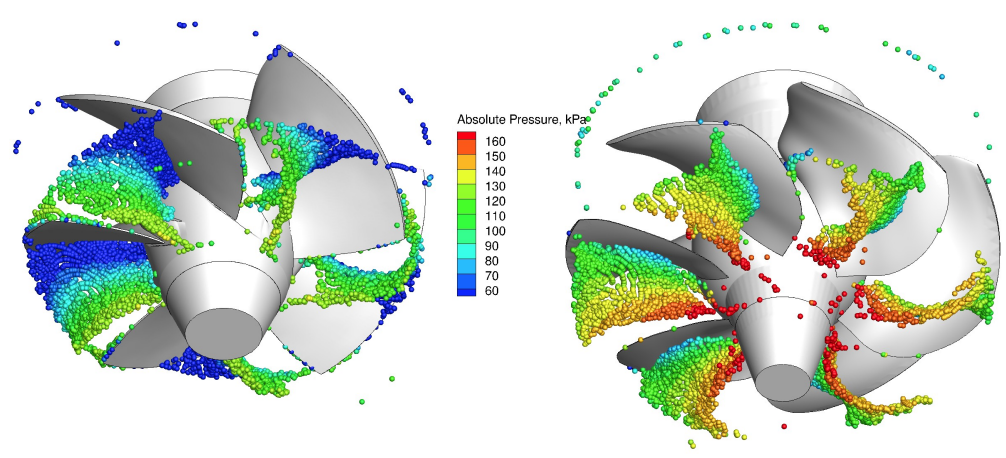

Figure 7. Location of Nadir Pressures from all Streamtraces from the Uniform Turbine-intake Distribution, in both the ORIG (left) and AHT (right) Units at a Nominal Discharge of $17 \mathrm{kcfs}$ 

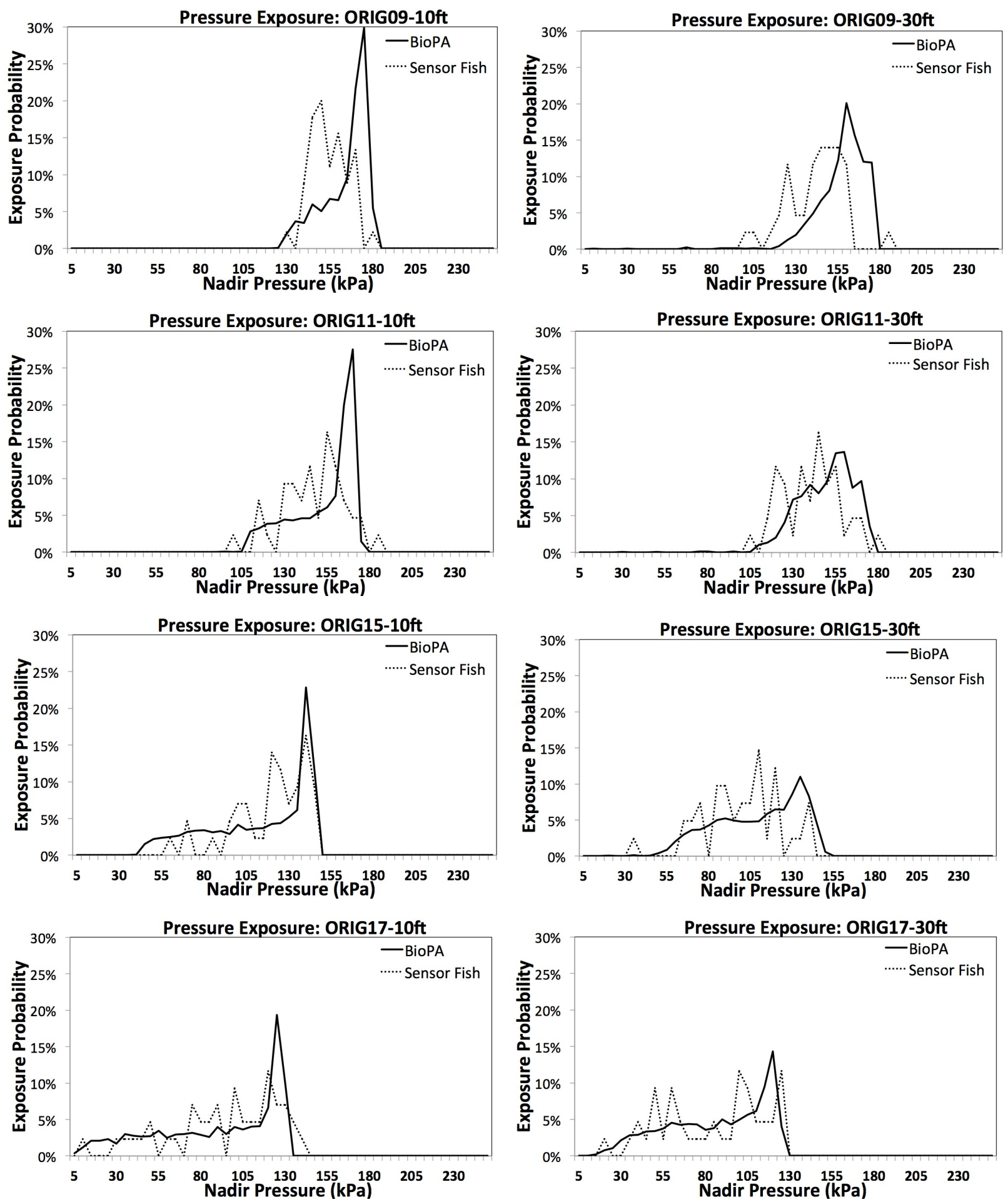

Figure 8. Nadir Pressure Frequency Distributions in the ORIG Turbine Design Cases are Computed from SF Data and the BioPA Calculations for Pipe Releases at $10 \mathrm{ft}$ (left) and $30 \mathrm{ft}$ (right) 

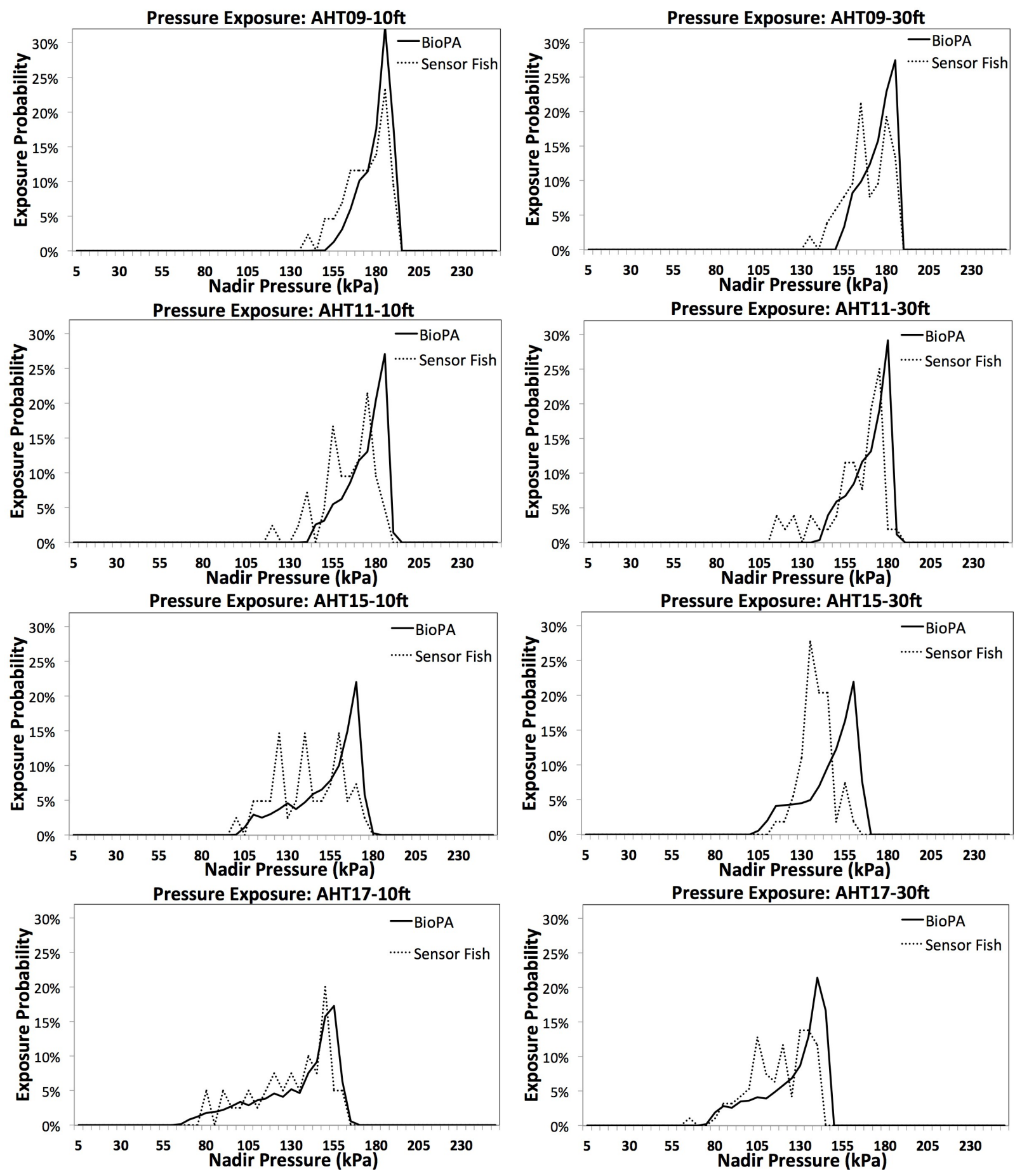

Figure 9. Nadir Pressure Frequency Distributions in the AHT Turbine Design Cases are Computed from SF Data and the BioPA Calculations for Pipe Releases at $10 \mathrm{ft}$ (left) and $30 \mathrm{ft}$ (right) 

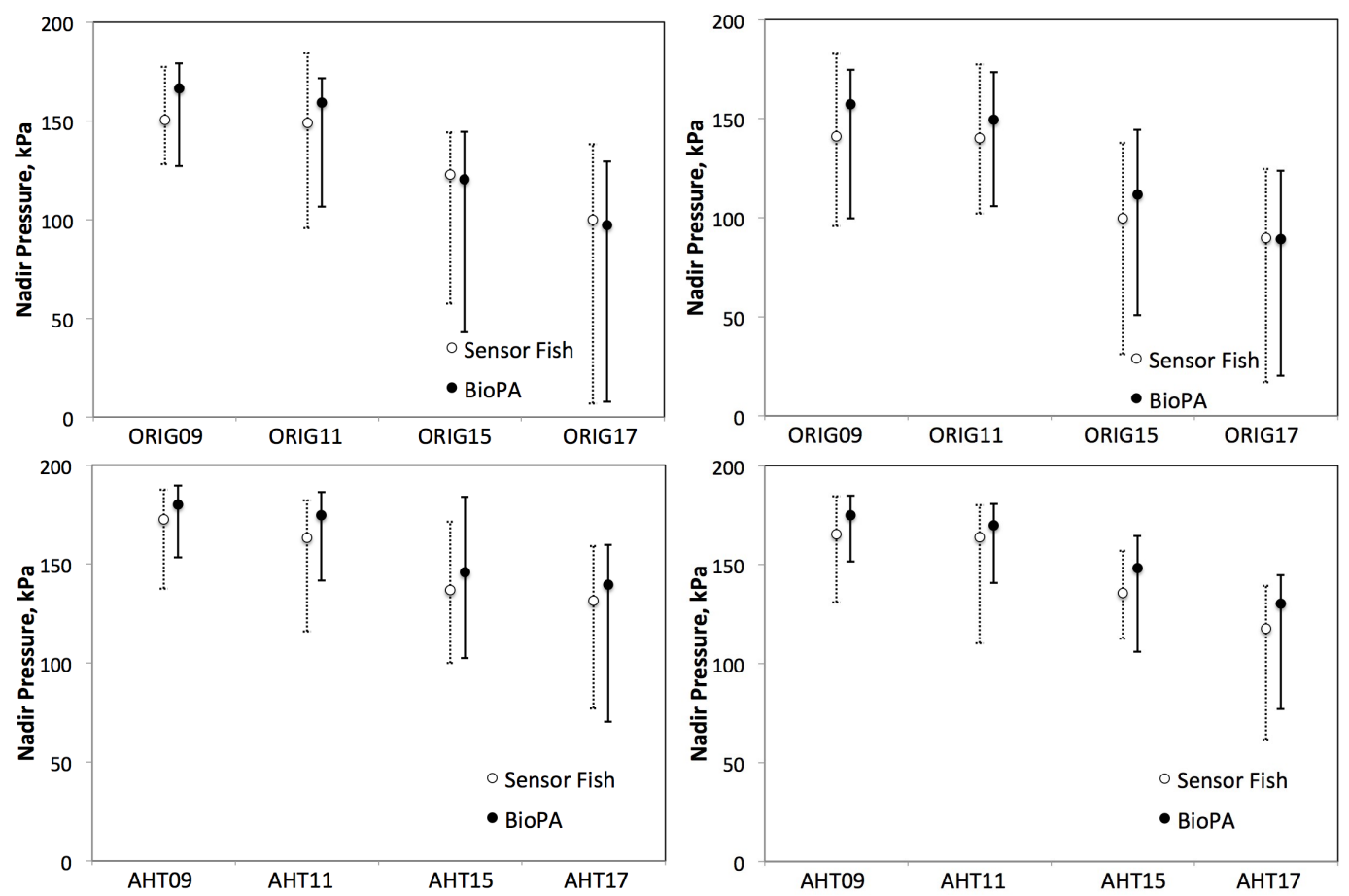

Figure 10. Median and Range Values of Nadir Pressure for the ORIG (top figures) and AHT (bottom figures) Units from Pipe Releases at $10 \mathrm{ft}$ (left) and $30 \mathrm{ft}$ (right) in All Discharge Scenarios

The BioPA method satisfactorily predicts the nadir pressures that fish en- counter during turbine passage. Both the BioPA-modeled and SF-measured values show that nadir pressure tends, as expected, to decrease with increasing discharge. Nadir pressures from SF and streamtrace releases at the 10-ft elevation tend to be higher than those released at $30-\mathrm{ft}$ elevation. Statistical measures of nadir pressure in Figure 10 show that barotrauma injuries are potentially less severe in the AHT unit than in the ORIG unit. This is true for all discharges at both release elevations, except from the maximum nadir pressure from a 10 -ft release at $11 \mathrm{kcfs}$. Based only on SF data, Dauble et al. (2007) also observed that a more adverse pressure environment was produced by the ORIG unit than by the AHT unit. The BioPA method acceptably reproduced two distinctive features of the field data distributions at increasing discharges: the tendencies to reduce pressure nadir exposure probability peaks and to increase the range (or variability) of the distribution.

The BioPA range and median nadir pressure values are generally greater than SF values from both release elevations for both the ORIG and AHT designs and for all discharge scenarios, except in the ORIG design at high discharges (Figure 10). Although uncertainties are present in the SF data due to the small sample size, another possible cause for such an offset could be the conversion from relative CFD pressure to absolute pressure. Revisiting the conversion calculations using time-varying tailwater surface elevation in each flow scenario will be examined in future work.

To evaluate the global risk to the fish population, Figure 11 shows the nadir pressure exposure frequency distribution for the discharge case with the lowest pressure conditions (ORIG17, 10-ft release pipe). The calculated risk of mortal injury associated with low-pressure exposure is enclosed under the two curves (shaded area). The performance score ( $\beta$ in Eq. 3) was $84 \%$, or a global mortal injury rate from pressure exposure of about $16 \%$. The performance scores were calculated in a similar fashion for all treatments (Figure 12). 
The dose-response relationship between mortal injury and nadir pressure does not necessarily reflect the actual risk related to barotrauma (see the "mortal injury" curve in Figure 11). Numerous events of higher pressure values are inconsequential to the total risk in comparison to few instances of very low nadir pressures. Figure 12 shows scores for both designs, at the four discharges from both release pipes and based on both the simulated (BioPA) and measured (SF) nadir pressure distributions. For the AHT unit, the scores are insensitive to the release pipe elevation and changed slightly across the discharges. Both the BioPA and SF scores indicate that from the perspective of fish passage, the pressure environment worsens considerably at high discharges $(17 \mathrm{kcfs})$ in the original turbine. Based on the modeled pressure scores, the AHT design achieves an overall superior performance in terms of reduced mortal injury rates as compared to the ORIG design.

To evaluate the sensitivity to the seeding locations, the statistics of nadir pressure arising from the fyke net and uniform seed distribution, as well as from the pooled SF data, are depicted in Figure 13. SF data were pooled by merging the two pipe-release samples, thereby resulting in larger sample sizes between 90-100 releases. The minimum, median and maximum measurements from SF data were respectively compared with the 1-, 50-, and 99-percentiles distributions from the fyke net and uniform distribution BioPA results.

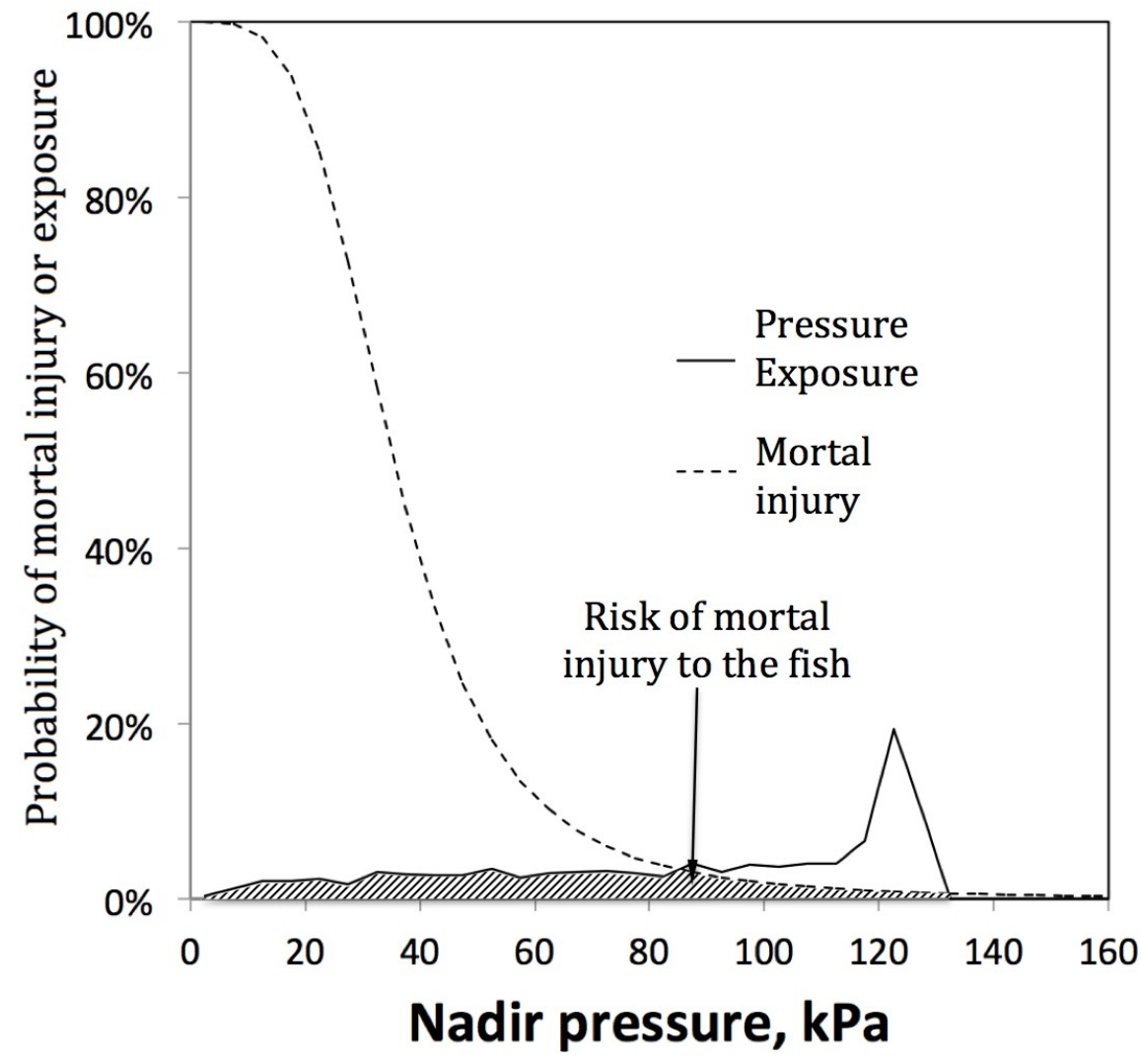

Figure 11. An Example of the Quantitative Risk of Mortal Injury to the Fish Population in Treatment ORIG17, $10 \mathrm{ft}$-release Pipe. The mortal injury curve is for a $5 \mathrm{~m}$ acclimation depth. 

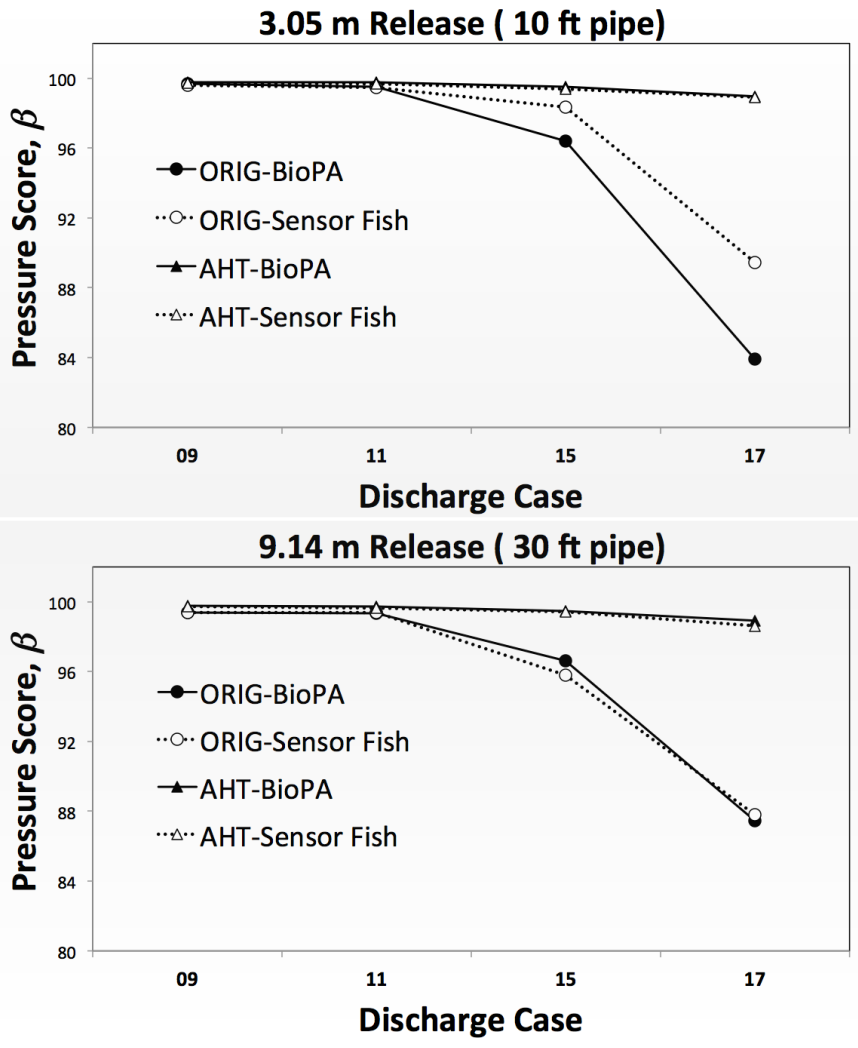

Figure 12. BioPA- and SF-based Scores of Pressure Stressor from the $10 \mathrm{ft}$ (top) and $30 \mathrm{ft}$ (bottom) Release Pipes, for all Discharges

In summary, the results showed three consistent patterns: nadir pressures decreased with increasing discharge, nadir pressure values were always greater for the AHT unit than for the corresponding ORIG unit cases, and the uniform seed distribution yielded median values that were typically bounded by the other two datasets (SF and fyke net). The latter shows that the uniform seeding effectively sampled an extent of the flow volume in the turbine runner zone, a situation that tended to average out possible nadir pressure conditions.

The BioPA performance scores exhibited limited sensitivity to either modeled seed distribution in Figure 14 (uniform and fyke-net curves overlap). Taking the SF scores as a baseline, the ORIG unit produced fewer discrepancies from the pipe-release seed distribution (Figure 12) than from the uniform and fyke-net distributions (Figure 14). At higher discharges the reason for the lower BioPA pressure scores as compared to those from SF is illustrated in Figure 15. The BioPA samples are both larger in number and also sample a larger zone of probable passage routes through the turbine than the live fish and SF. Thus, BioPA captures increased exposure to lower pressure nadirs which in turn drive increased rates of mortal injury resulting in a lower score from BioPA. Therefore, the BioPA results reveal that field studies using point releases (pipes) for live fish and SF are likely to produce information that may not be entirely descriptive of conditions encountered by actual run-of-river fish populations, the distribution of which may be better represented by the fyke-net frequencies. For the AHT unit, all methods score virtually the same values since the overall absolute pressure within the new turbine design is predominately above $80 \mathrm{kPa}$ where the rate of mortal injury rapidly decreases with increasing nadir pressure. This analysis demonstrates the flexibility of the BioPA method to accommodate realistic fish distributions to achieve a more representative assessment of the biological performance of hydropower turbines. 
Finally, the experimental design of biological performance tests of hydro-turbines typically selects a set of test parameters such as release locations of live fish or SF, sample size, sample distribution, etc. The method presented here can potentially aid in the experimental design for the optimal deployment of sensors and equipment which are expected to produce the largest amount of meaningful onsite information to evaluate and compare among unit designs from the standpoint of fish passage safety. The BioPA method can also be of value to perform biological assessments of existing turbines or other fish passage routes.

\subsection{Summary and Conclusions}

This study developed and applied a method to evaluate mortal injury caused by exposure to low pressures encountered by fish during turbine passage. A case study at Wanapum Dam was used to compare the outcomes across turbine designs, discharge, and sample release locations. The results show the ability of the BioPA method to characterize the pressure conditions with a quality comparable to sensor data obtained from field studies of real-world turbine flows. Based on performance scores for nadir pressure exposure, the AHT turbine design is better than, or at least as good as the ORIG design, while also having a higher power output. In terms of discharge, we found, as expected, that the higher the discharge, the more adverse the pressure conditions for fish and, in turn, the higher the probable mortal injury rate. A number of spatial sampling strategies showed that the BioPA scores are influenced by the location, density, and distribution of the fish sample at the moment of entrainment at the turbine intake. The outcomes of the BioPA can be used to support comparative decision making (ranking) in the process of retrofitting, upgrading, and replacing turbines when the selection criteria include enhanced biological performance.

Future work will address other injury mechanisms such as blade strike, shear, and turbulence in order to provide a more complete picture of the hydraulic risks encountered by fish during turbine passage. 

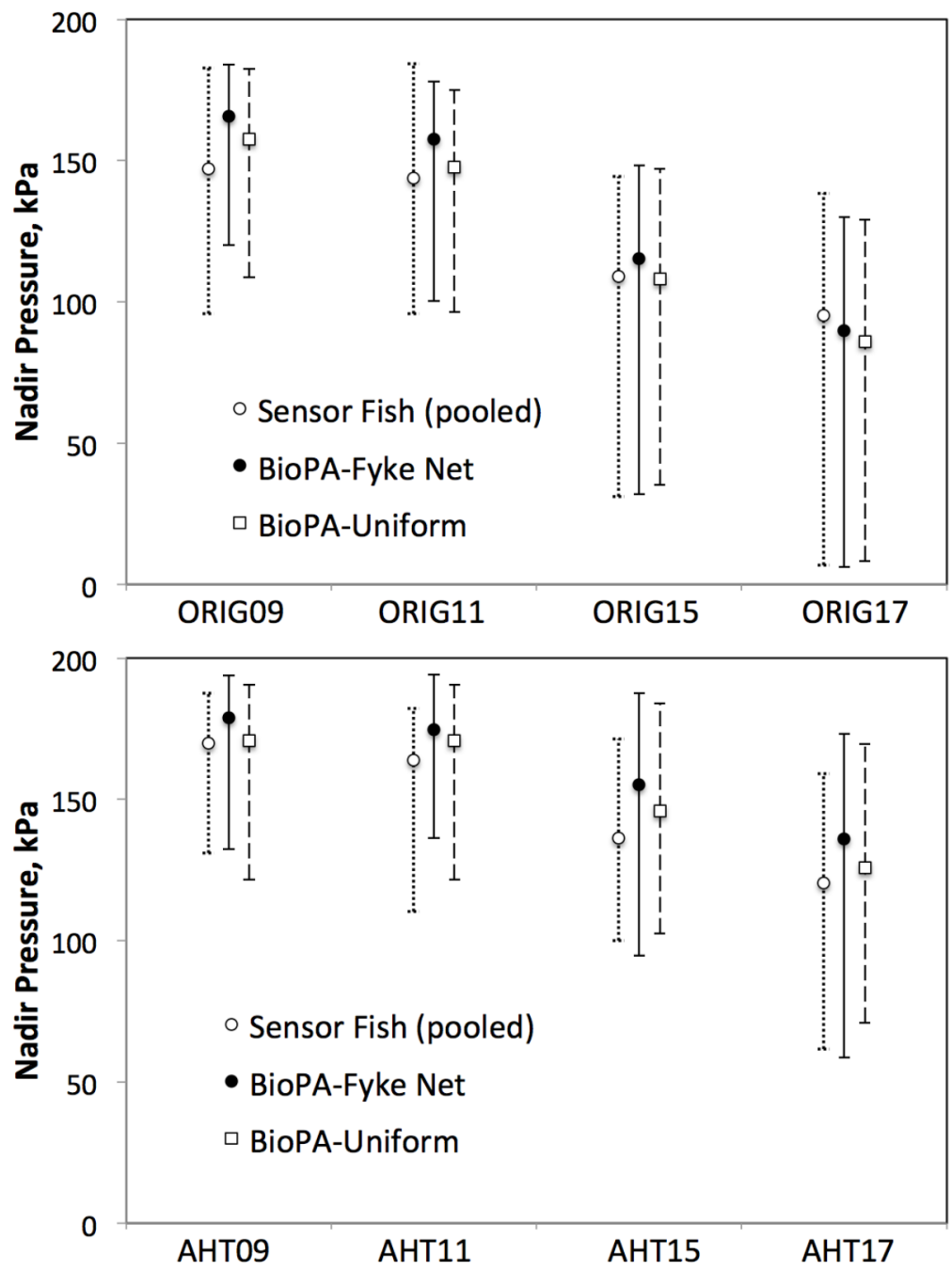

Figure 13. Median and Range Values of Nadir Pressure from the SF Data and Modeling Approach with Uniform and Fyke-net Seeding Schemes 

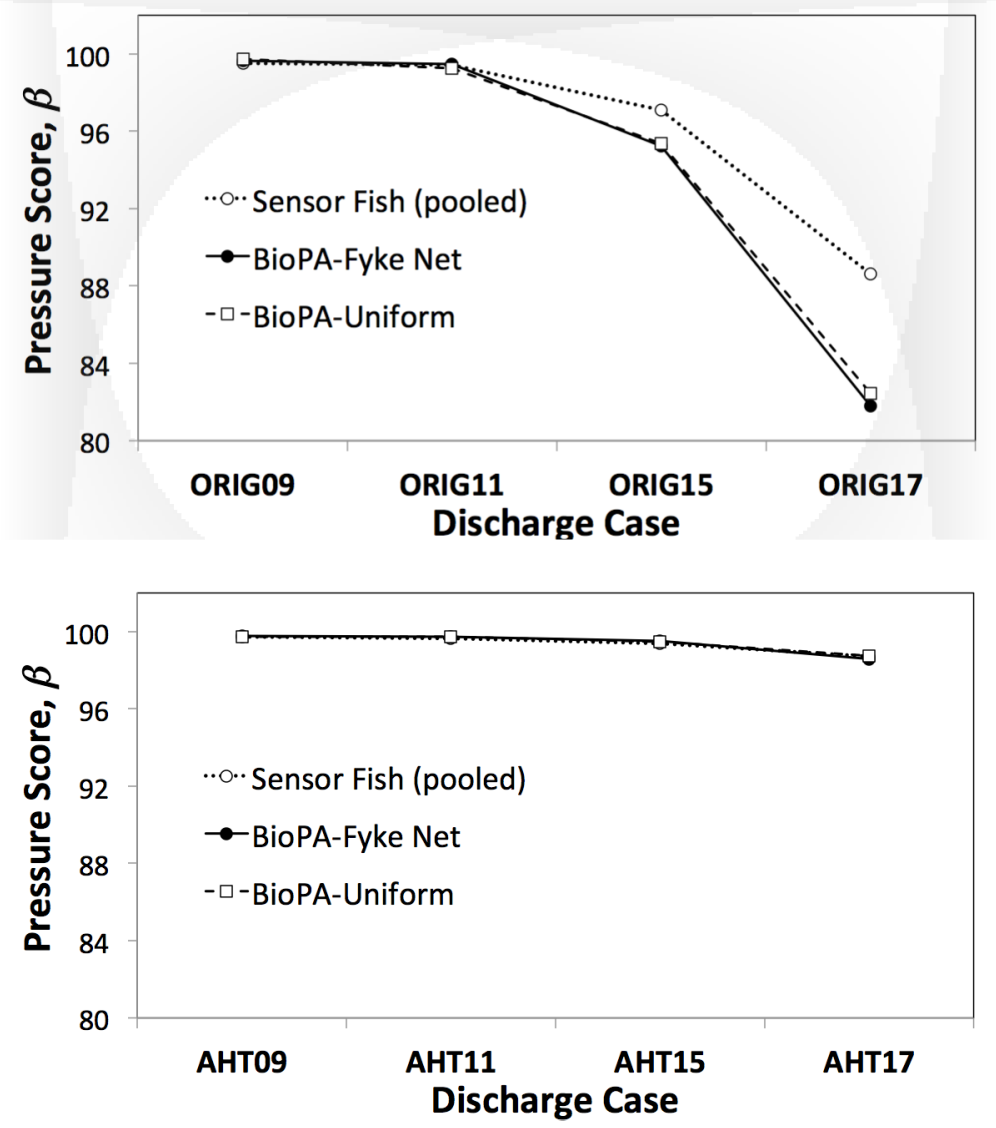

Figure 14. Pooled SF-based Scores and BioPA Scores from Fyke Net and Uniform Seed Distributions, for All Discharge Cases

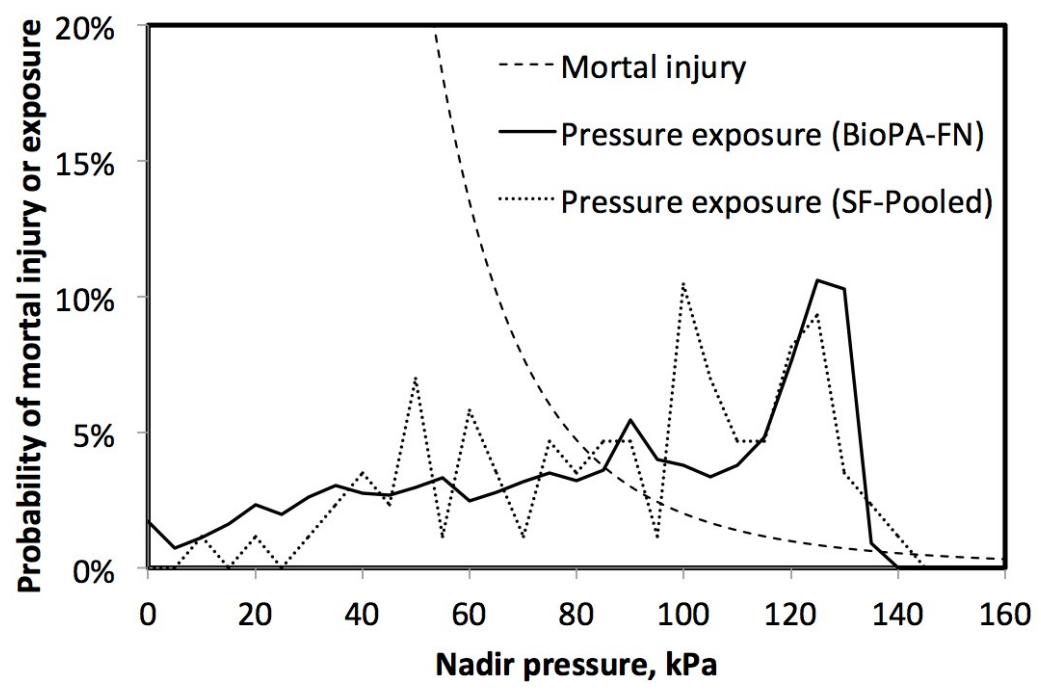

Figure 15. Probability of Exposure and Mortal Injury (acclimation depth $5 \mathrm{~m}$ ) for ORIG17 Case. The distributions are pooled data all release pipes for the BioPA (fyke net) and SF. 
Overall, the results show that modern Kaplan turbine designs can achieve both hydraulic benefits such as increased power and lower cavitation potential while at the same time reducing barotrauma risk to passing fish from exposure to low pressures.

\subsection{References}

Abernethy C, B Amidan, and G Cada. 2001. "Laboratory studies of the effects of pressure and dissolved gas supersaturation on turbine-passed fish." PNNL-13470. Pacific Northwest National Laboratory. Richland, Washington.

Abernethy C, B Amidan, and G Cada. 2002. "Simulated passage through a modified Kaplan turbine pressure regime: A supplement to Laboratory studies of the effects of pressure and dissolved gas supersaturation on turbine-passed fish." PNNL-13470-A. Pacific Northwest National Laboratory. Richland, Washington.

Brown RS, TJ Carlson, AJ Gingerich, JR Stephenson, BD Pflugrath, AE Welch, MJ Langeslay, ML Ahmann, RL Johnson, JR Skalski, AG Seaburg, and RL Townsend. 2012a. "Erratum: Quantifying mortal injury of juvenile chinook salmon exposed to simulated hydro-turbine passage." Transactions of the American Fisheries Society 141: 570-570.

Brown RS, TJ Carlson, AJ Gingerich, JR Stephenson, BD Pflugrath, AE Welch, MJ Langeslay, ML Ahmann, RL Johnson, JR Skalski, AG Seaburg, and RL Townsend. 2012b. "Quantifying mortal injury of juvenile chinook salmon exposed to simulated hydro-turbine passage." Transactions of the American Fisheries Society 141: 147-157.

Brown RS, BD Pflugrath, AH Colotelo, CJ Brauner, TJ Carlson, ZD Deng, and AG Seaburg. 2012c. "Pathways of barotrauma in juvenile salmonids exposed to simulated hydroturbine passage: Boyle's law vs. Henry's law." Fisheries Research 121-122, 43 - 50.

Čada G, C Coutant, and R Whitney. 1997. "Development of biological criteria for the design of advanced hydropower turbines.” DOE/ID- 10578. Idaho National Laboratory. Idaho Falls, Idaho.

Čada G, J Loar, L Garrison, RJ Fisher, and D Neitzel. 2006. "Efforts to reduce mortality to hydroelectric turbine-passed fish: Locating and quantifying damaging shear stresses." Environmental Management 37 : 898-906.

Carlson T, Duncan, J., Deng, Z., 2008. Data overview for sensor fish samples acquired at Ice Harbor, John Day, and Bonneville II Dams in 2005, 2006, and 2007. Technical Report PNNL-17398. Pacific Northwest National Laboratory. Richland, Washington.

Carlson T, J Duncan, T Gilbride, and G Keilman. 2004. "The Sensor Fish - Making dams more salmonfriendly." Sensors Magazine 21: 31-34.

Carlson TJ and JP Duncan. 2003. "Evolution of the sensor fish device for measuring physical conditions in severe hydraulic environments." PNNL-15708. Pacific Northwest National Laboratory. Richland, Washington. 
Carlson TJ, JP Duncan, and ZD Deng. 2006. "Use of the sensor fish device to evaluate the biological performance of an advanced turbine design at Wanapum Dam in 2005." PNWD-3743. Pacific Northwest National Laboratory. Richland, Washington.

Carlson TJ, JP Duncan, and T Gilbride. 2003. "The sensor fish: measuring fish passage in severe hydraulic conditions." Hydro Review 22, 62-69.

CD-adapco. 2013. User Guide, STAR-CCM+ Version 8.02. CD-adapco.

Colotelo AH, BD Pflugrath, RS Brown, CJ Brauner, RP Mueller, TJ Carlson, ZD Deng, ML Ahmann, and BA Trumbo. 2012. "The effect of rapid and sustained decompression on barotrauma in juvenile brook lamprey and Pacific lamprey: Implications for passage at hydroelectric facilities." Fisheries Research 129-130: $17-20$.

Coutant CC and RR Whitney. 2000. "Fish behavior in relation to passage through hydropower turbines: A review." Transactions of the American Fisheries Society 129: 351-380.

Cramer F and R Oligher. 1964. "Passing fish through hydraulic turbines." Transactions of the American Fisheries Society 93: 243-250.

Dauble D, Z Deng, M Richmond, R Moursund, T Carlson, C Rakowski, and J Duncan. 2007. "Biological assessment of the advanced turbine design at Wanapum Dam, 2005." PNNL-16682. Pacific Northwest National Laboratory. Richland, Washington.

Deng Z, TJ Carlson, JP Duncan, and MC Richmond. 2007. "Six-degree-of-freedom sensor fish design and instrumentation." Sensors 7: 3399-3415.

Deng Z, TJ Carlson, JP Duncan, MC Richmond, and DD Dauble. 2010. "Use of an autonomous sensor to evaluate the biological performance of the advanced turbine at Wanapum Dam." Journal of Renewable and Sustainable Energy 2: 053104.

Enders EC, D Boisclair, and AG Roy. 2003. "The effect of turbulence on the cost of swimming for juvenile Atlantic salmon (Salmo salar).” Canadian Journal of Fisheries and Aquatic Sciences 60: 11491160 .

EPRI - Electric Power Research Institute. 2008. "Evaluation of the effects of turbine blade leading edge design on fish survival." Technical Report 1024569. Electric Power Research Institute. Palo Alto, California.

Galvan S, M Reggio, and F Guibault. 2011. "Assessment study of k- $\epsilon$ turbulence models and near-wall modeling for steady state swirling flow analysis in draft tube using FLUENT." Engineering Applications of Computational Fluid Mechanics 5: 459-478.

Garrison L, R Fisher, M Sale, and G Čada. 2002. "Application of biological design criteria and computational fluid dynamics to investigate fish survival in Kaplan turbines." In Proceedings of HydroVision 2002, Portland, Oregon.

Hellstrom JGI, BD Marjavaara, and TS Lundstrom. 2007. "Parallel CFD simulations of an original and redesigned hydraulic turbine draft tube." Advances in Engineering Software 38: 338-344. 
Keller M, M Sick, R Grunder, and P Grafenberger. 2006. "CFD-Based assessment of fish-friendliness of the time dependent flow field in a Kaplan runner." In Proceedings of HydroVision 2006, Portland, Oregon.

Khan L, E Wicklein, M Rashid, L Ebner, and N Richards. 2004. "Computational fluid dynamics modeling of turbine intake hydraulics at a hydropower plant." Journal of Hydraulic Research 42: 61-69.

Liu S, Y Wu, and X Luo. 2005. "Numerical simulation of 3D cavitating turbulent flow in Francis turbine." In Proceedings of the ASME Fluids Engineering Division Summer Conference - 2005, Vol. 1, Pts A and B, Houston, Texas. pp. 1551-1556.

Meselhe E, L Weber, A Odgaard, and T Johnson. 2000. "Numerical modeling for fish diversion studies." Journal of Hydraulic Engineering 126: 365-374.

Neitzel D, D Dauble, G Čada, M Richmond, G Guensch, R Mueller, C Abernethy, and B Amidan. 2004. "Survival estimates for juvenile fish subjected to a laboratory-generated shear environment." Transactions of the American Fisheries Society 133: 447-454.

Nilsson H and L Davidson. 2003. "Validations of CFD against detailed velocity and pressure measurements in water turbine runner flow." International Journal for Numerical Methods in Fluids 41: 863-879.

NMFS - National Marine Fisheries, Service. 2008. "Biological Opinion - Consultation on remand for operation of the Federal Columbia River power system." National Oceanic and Atmospheric Administration.

Normandeau Associates, JR Skalski, and RL Townsend. 2005. "Performance evaluation of the new advanced hydro turbine (AHTS) at Wanapum Dam, Columbia River, Washington." Normandeau Associates Inc. Drumore, Pennsylvania.

Olson FW. 1984. "Vertical distribution of juvenile salmonids entering the turbine intakes at Wanapum Dam.” CH2M HILL. Public Utility District No. 2 of Grant County, Ephrata, Washington.

Paik J, F Sotiropoulos, and M Sale. 2005. "Numerical simulation of swirling flow in complex hydroturbine draft tube using unsteady statistical turbulence models." Journal of Hydraulic Engineering 131: 441-456.

Pflugrath BD, RS Brown, and TJ Carlson. 2012. "Maximum neutral buoyancy depth of juvenile Chinook salmon: Implications for survival during hydroturbine passage." Transactions of the American Fisheries Society 141: 520-525.

Richmond M, J Serkowski, L Ebner, M Sick, R Brown, and T Carlson. 2014a. "Quantifying barotrauma risk to juvenile fish during hydro-turbine passage." Fisheries Research 154: 152-164.

Richmond MC, TJ Carlson, JA Serkowski, CB Cook, JP Duncan, and WA Perkins. 2007. "Characterizing the fish passage environment at The Dalles Dam spillway: 2001-2004." PNNL-16521. Pacific Northwest National Laboratory. Richland, Washington.

Richmond MC, Z Deng, CA McKinstry, RR Mueller, TJ Carlson, and DD Dauble. 2009. "Response relationships between juvenile salmon and an autonomous sensor in turbulent flow." Fisheries Research 97: 134-139. 
Richmond MC, JA Serkowski, CL Rakowski, B Strickler, M Weisbeck, and CL Dotson. 2014b. "Computational tools to assess turbine biological performance." Hydro Review 33: 88-98.

Roh HW, SH Suh, Jh Jung, and S Oh. 2010. "Development of a high performance Francis turbine for runner replacement using a CFD-based design system." In Proceedings of the ASME Fluids Engineering Division Summer Conference - 2010 - Vol. 1, PTS A-C, ASME, Fluids Engn Div. pp. 843-848. 3rd Joint U.S.-European Fluids Engineering Division Summer Meeting, Montreal, Canada, August 01-05, 2010.

Ventikos Y, F Sotiropoulos, and R Fisher. 1997. "Predicting fish passage through hydropower installations.” In Proceedings of Waterpower 1997, Atlanta, Georgia. pp. 140-149. 


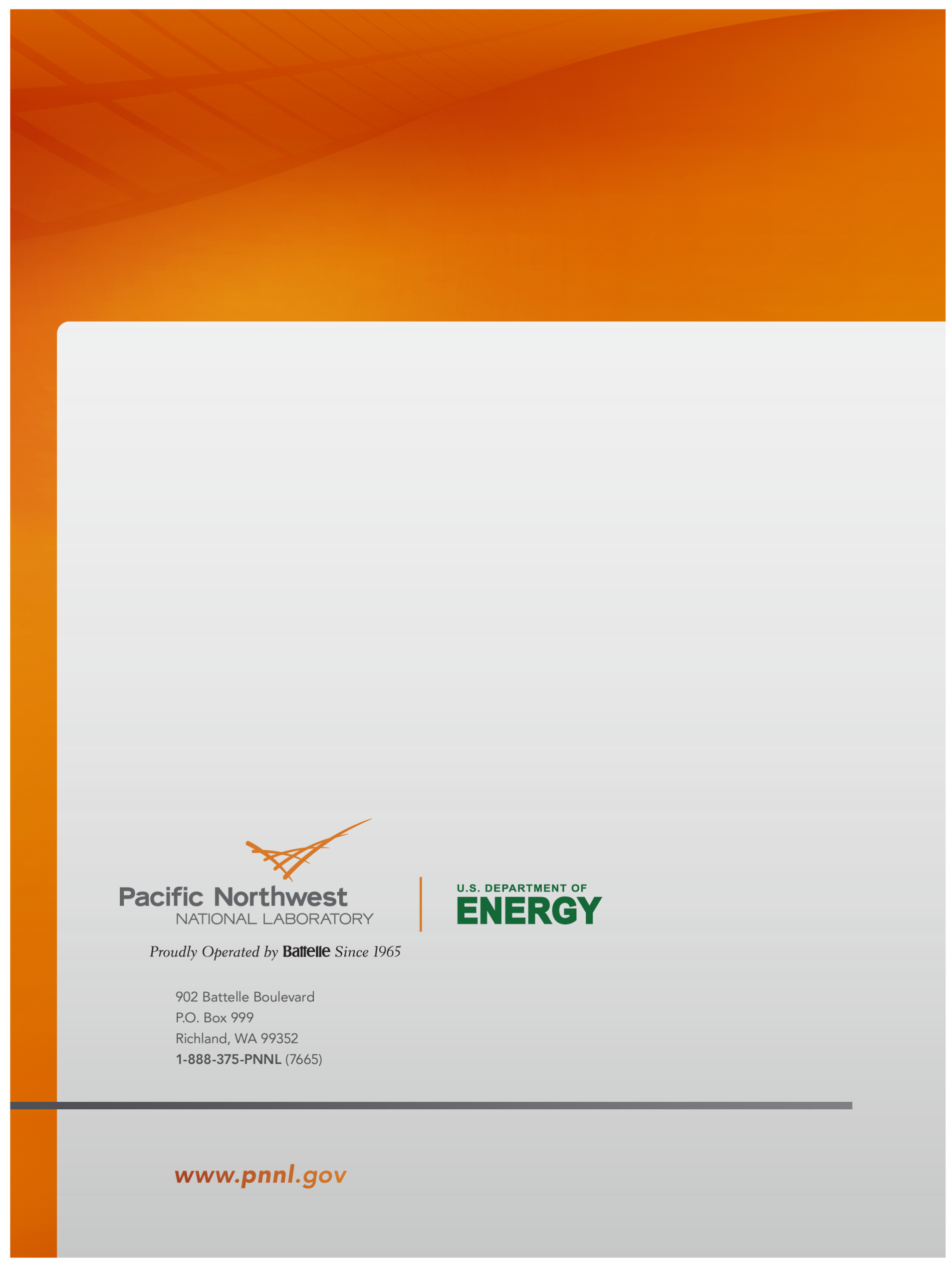

